Balçın, M. D. \& Yavuz Topaloğlu M. (2018)Gelecekte seçmek istedikleri mesleklere ilişkin öğrenci görüşleri. Abant İzzet Baysal Üniversitesi Ĕgitim Fakültesi Dergisi, 18 (3), 1331-1359.

Geliş Tarihi: 09/01/2018

Kabul Tarihi: 21/09/2018

\title{
GELECEKTE SEÇMEK İSTEDİKLERİ MESLEKLERE İLISSTIIN ÖĞRENCİ GÖRÜŞLERİ
}

\author{
Muhammed Doğukan BALÇIN* \\ Melike YAVUZ TOPALOĞLU**
}

\section{ÖZET}

$\mathrm{Bu}$ çalışmanın amacı, meslek seçiminin kritik döneminde olan ortaokul düzeyindeki öğrencilerinin gelecekte seçmek istedikleri mesleklerin neler olduğunu ortaya çıkarmak ve bu mesleklerde çalışan kişilerin kişisel özellikleri, yaptıkları işler ile hangi meslek çalışanları ile yakınlık gösterdikleri hakkındaki düşüncelerini belirlemektir. Çalışmada nitel araştırma desenlerinden fenomenoloji (olgubilim) deseni kullanılmıştır. Bu araştırmanın çalışma grubunu 2016-2017 eğitim öğretim yılında Bitlis ili Adilcevaz ilçesinde bulunan bir ortaokulda öğrenim görmekte olan 53 altıncı sınıf ögrencisi oluşturmaktadır. Çalışma grubunun belirlenmesinde uygun örnekleme yöntemi kullanılmıştır. Veri toplama aracı olarak 4 açık uçlu soru içeren bir form kullanılmıştır. Elde edilen veriler ise içerik analizi ile değerlendirilmiştir. Araştırmanın sonucunda öğrencilerin günlük hayatta karşılaştığı mesleklere daha çok yöneldiği diğer meslek grupları hakkında yeterli bilgilerinin olmadığı belirlenmiştir. Diğer bir sonuç olarak öğrencilerin bazı benzer meslek grupları arasında yanılgılara sahip oldukları, meslek gruplarında yer alan bireylerin özellikleri hakkında doğru fakat basit düzeyde bilgilerinin olduğu tespit edilmiştir.

Anahtar Kelimeler: Ortaokul öğrencileri, meslek seçimi, meslek özellikleri

\section{STUDENTS' OPINIONS ABOUT PROFESSIONS THAT THEY WANT TO CHOOSE IN THE FUTURE}

\begin{abstract}
The purpose of this study is to find out about the professions which the secondary school students who are in the critical period of choosing a profession want to choose in the future and determine their thoughts on the personal characteristics of the people within these professions, the professions they are in and the professionals they are sympathizing with. In the study, the phenomenology model from the qualitative research models was used. The study group of this research consist of 53 6th grade students studying in a secondary school located in the Adilcevaz District of Bitlis Province during the academic year of 2016-2017. In the determination of the study group, convenience sampling method was used. A form including 4 open ended questions was used as a data collection tool. The data obtained was evaluated with the content analysis. The result of the research shows that students mostly tend to choose professions that they encounter in their daily lives and they have inadequate knowledge about other professions. As another result, it was determined that they have misconception between some similar professions groups and they have accurate but simple knowledge about the personal characterictics of people in these professions.
\end{abstract}

Key Words: Secondary school students, career choosing, professional characteristics

* Doktora ögrencisi, Marmara Üniversitesi, Ĕ̆itim Bilimleri Enstitüsü, Fen Bilgisi Öğretmenliği, dogukanbalcin@gmail.com

${ }^{* *}$ Dr., Milli Eğitim Bakanlığı,meykeyavuz@hotmail.com 
Muhammed Doğukan BALÇIN, Melike YAVUZ TOPALOĞLU

\section{GİRIŞ}

Türkiye başta olmak üzere dünya çapında çeşitli ülkelerde işsizlik ve işinden memnun olmama durumları yaygın olarak karşılaşılan sosyal sorunlar haline gelmiştir. Yapılan çalışmalar, işinde mutlu olmayan ve özellikle genç yaşta iş bulamayan birey sayısının her geçen gün katlandığını ortaya koymaktadır (Organization for Economic Cooperation and Development- Ekonomik Kalkınma ve İşbirliği Örgütü [OECD], 2014; Sukiennik, Bendat ve Raufman, 2004; Türkiye İstatistik Kurumu [TÜİK], 2017). Bu bulgulara bağlı olarak bireylerin kariyer bilinci kazanma ve meslek tercihleri konusunda bir takım eksikliklerinin var olduğu ifade edilebilir. Oysaki bilim ve teknoloji başta olmak üzere çeşitli alanlarda hızlı değişimlerin yaşandığı ve ülkeler arası rekabetin giderek arttığı bilgi çağında toplumların ihtiyaç duyduğu meslek gruplarında yer alacak donanımlı bireylerin yetiştirilmesi bireyin kendini gerçekleştirmesinin yanı sıra toplumun gelişiminde de etkin rol oynamaktadır (Yeşilyaprak, 2011). Bu bağlamda kişinin meslek seçiminin hem kendisi hem de içinde bulunduğu toplum için büyük bir anlamı olan ciddi bir süreç olduğu vurgulanabilir. Dolayısıyla kişinin ilgi, yetenek ve isteğine bağlı olarak doğru mesleği seçmesi başarıll, mutlu ve verimlilikle dolu bir yaşam sürmesini sağlamaktadır. Buna karşın ilgi, yetenek ve isteğine bağlı kalmaksızın yapılan yanlış meslek tercihleri ise; kişinin başarısız, verimsiz ve mutsuz olmasına neden olmaktadır (Yanıkkerem, Altınparmak ve Karadeniz, 2004). Bireyin seçtiği meslek ile uyum içerisinde olması; kendine olan saygısının ve yaşamının kalitesinin artması anlamında kişilik ve psikolojik gelişimi için ve ayrıca topluma fayda sağlaması noktasında etkilidir. Bireyin kendine olan saygısının artması ve yaşam kalitesinin yükselmesi seçtiği meslek ile uyum içerisinde olması ile bağlantılıdır. $\mathrm{Bu}$ durum bireyin kişilik ve psikolojik gelişimi açısından olumlu bir şekilde etkilenmesine; buna bağlı olarak da topluma faydalı olmasını sağlamaktadır (Mcintosh, 2000). Bireyin meslek seçimi yaşam tarzını biçimlendirme noktasında kişinin hayatında yapacağı en önemli tercihlerden birisidir (Kuzgun, 1986). Şüphesiz eğitim-öğretim sürecini tamamlayan bir birey, tüm yaşamını etkileyecek olan meslek seçimi sorunu ile karşı karşıya kalır. İnsan hayatının dönüm noktası olan meslek kavramı "Bir kimsenin hayatını kazanmak için yaptığı, diğer insanlara yararlı bir hizmet ya da ürün sağlamaya yönelik olan, kuralları toplumca belirlenmiş ve belli bir eğitimle kazanılan bilgi ve becerilere dayalı etkinlikler bütünü” olarak tanımlanır (Herr, Cramer ve Niles, 2004, s. 44).

Meslek gelişimi kökenleri ilk ve ortaokul dönemine uzanan kişinin çocukluğundan itibaren oluşan yaşam boyu gelişim gösteren bir süreçtir. İlk ve ortaokul yılları bireylerin meslekler hakkında tercih yapabilecek yeterliliğe ulaşmaları için mesleklerle ilgili bilgi, tutum ve davranışlar kazandıkları çağlardır (Gottfredson, 2002). Meslek seçimi, mesleki olgunluk düzeyi ve öğrencilerin ilgi ve yeteneklerini keşfetme, meslekler hakkında yeterli ve doğru bilgiye sahip olma gibi mesleki görevleri ile ilişkilidir (Çoban, 2005). Super (1963) "kariyer" kavramını ilk kez öneren kuramcı olmakla beraber, ilk araştırmaların çocuklardan ziyade ergenler, üniversite öğrencileri ve yetişkinler üzerinde yapmıştır. Fakat Super (1990) tarafından çocukların kariyer gelişiminin önemli olduğu vurgulanmış ve incelenmesi gerektiği belirtilmiştir. $\mathrm{Bu}$ anlamda özellikle ortaokul yılları bireyin mesleklere karşı olan ilgi ve bilgilerinin arttı̆g 1 ve kararlarının netleştiği yıllar olması bakımından önemlidir (Deniz, 2001). Bu nedenle ortaokulda meslekler ilgili bilgilerin kazandırıldığı derslerin (Fen bilimleri, Sosyal bilgiler, T.C. İnkılap Tarihi ve Atatürkçülük vb.) öğretim programlarında meslek ve 
Gelecekte seçmek istedikleri mesleklere ilişkin öğrenci görüşleri

kariyer bilinci vurgulanmıștır. Örneğin; fen bilimleri öğretim programın da FenTeknoloji- Toplum- Çevre (FTTÇ) öğrenme alanı kapsamında Fen ve Kariyer Bilinci başlığı altında fen alanındaki meslekleri tanımak, bilimsel bilginin ilerleyiş̧ine etkisini öğrenmek kısacası bu mesleklerin farkında olmak hedeflenmiştir. $\mathrm{Bu}$ şekilde öğrencilerin fen bilimleri ile ilgili kariyer bilincinin geliştirilmesi amaçlanmıştır (MEB, 2013). Öğretim programlarının amaçlarından yola çıkıldığında bireyin kendine uygun meslek seçimini yapma ve kariyer bilinci kazanma anlamında yeterliliğe sahip olması eğitim- öğretim hayatının ilk yıllarını kapsadığını göstermektedir. Oysa bu konuya ilişkin ortaokul ve ilkokul öğrencileri ile yürütülen çalışmaların oldukça az olduğu tespit edilmiştir (Can ve Taylı, 2014).

Literatürde yer alan çalışmalar incelendiğinde; Bozgeyikli, Bacanlı ve Doğan (2009) mesleki grup rehberliğinin öğrencilerinin, meslek kararı vermede kendilerini yetkin görme düzeylerini incelediği çalışmasında öğrencilerin mesleki grup rehberliğinin öğrencilerin meslek kararı vermede kendilerini yetkin görme düzeylerini geliştirmede etkisi olduğunu tespit etmiştir. Turner ve Lapan (2005) 107 ortaokul öğrencisi ile yürüttükleri deneysel çalı̧̧ma kapsamında geleneksel olmayan mesleklere olan ilginin artış gösterdiğini ve mesleki yetkinlik düzeylerinin anlamlı olarak farklılaşığını bulmuştur. Bozgeyikli (2008) çalışmasında ise; kariyer gelişimi ve cinsiyet değişseninin beraber meslek kararı verme öz yetkinlik algısının üç alt boyutunu da anlamlı olarak yordadıkları sonucuna ulaşmıştır. Can ve Taylı (2014) ortaokul öğrencilerinin kariyer gelişimlerini araştırdığı çalışmalarında; sınıf düzeyi, algılanan sosyoekonomik düzey, anne ve babanın eğitim seviyesi ve akademik başarı arttıkça kariyer gelişiminin yükseldiğini tespit etmiştir. Canal (2013) sosyal bilgiler dersinde mesleklerle ilgili olarak yürütülen etkinliklerin ortaokul öğrencilerinin meslek seçimi üzerindeki etkisini araştırdığı çalışmasında; bu etkinliklerin beşinci ve altıncı sınıf öğrencilerinin meslek tercihlerini etkilediği sonucuna ulaşmıştır. Ünlü (2010) ve Özen (2010) televizyonun meslek seçimi ve mesleki gelişim süreci üzerindeki etkisi üzerine çalışmalar yürütmüş̧ ve bu konularda televizyonun etkili olduğu sonucuna ulaşmışlardır. Işıklar ve Bozgeyikli (2010) 8. sınıf öğrencilerinin kariyer gelişimlerinin demografik faktörler açısından inceledikleri çalışmalarında; cinsiyet, anne ve baba eğitim seviyesi, sosyo ekonomik durumun kariyer gelişimlerinden önemli değişkenler olduğunu belirtmişlerdir Aktın (2017) çalışmasında kariyer bilinci geliştirmeye yönelik eğitim almış 6. sınıf kız öğrencilerinin bu bilinçlerini belirlemeyi amaçlamı̧̧ır. $\mathrm{Bu}$ araştırma sonucunda; öğrencilerin mesleki tercihlerini ilgi alanlarına göre belirledikleri sonucuna ulaşılmıştır.

\subsection{Araştırmanın Amacı}

İlk ve orta öğretim çağlarında öğrenciler tarafından alınan kararlar ve elde edilen bilgi ve becerilerin meslek seçiminde temel işleve sahip olduğu düşünüldüğünde; bu çalışma ile ortaokul 6. sınıf öğrencilerinin gelecekte seçmek istedikleri mesleklere ilişkin görüşlerinin belirlenmesi amaçlanmıştır.

\subsection{Araștırmanın Önemi}

$\mathrm{Bu}$ araştırma ile ortaokul düzeyinde yer alan öğrencilerin ilgi duyduğu mesleklerin neler olduğunun ortaya çıkarılması ve bu mesleklerde çalışan kişilerin hangi işlerle uğraştıkları hakkındaki düşüncelerinin belirlenmesi, meslek çalş̧anlarının kişisel 
özelliklerinin neler olduğuyla ilgili düşüncelerinin belirlenmesiyle öğrencilerin meslek ve çalışanlarıyla ilgili yanlış kavramaları var ise tespit edilecektir. Bu tespit öğrencilerin gelecek eğitim-öğretim hayatlarının daha sağlıklı şekillendirebilme ve kendilerine daha uygun meslek tercihleri yapabilmeleri açısından önemli görülmektedir. Bu bağlamda ortaokul öğrencileri ile yürütülen bu çalışmanın alana katkı sağlayacağı düşünülmektedir. Ayrıca ülkemizde meslek seçimi konusunda yeterli eğitimin verilememesine bağlı olarak yapılan yanlış meslek tercihleri; toplumda meslek hayatlarında mutsuz ve başarılı olamayan ya da iş bulmakta sıkıntı yaşayan bireylerin yer almasına neden olması bağlamında bu çalışma ortaokul öğrencilerinin meslekler hakkında var olan bilgilerinin, hayallerinin ve algılarının ortaya çıkarılması bakımından önemlidir.

\section{YÖNTEM}

\subsection{Araştırmanın Deseni}

Araştırma nitel araştırma yöntemlerinden olgubilim deseniyle yürütülmüştür. Olgubilim, kişilerin olguları nasıl algıladığı ve betimlediği, olguyu zihinlerinde nasıl oluşturup değerlendirdikleri ve başkalarına nasıl aktardıklarına ilişkin konuların derinlemesine araştırılmasına odaklanmaktadır (Patton, 2001). Bu kapsamda öğrencilerin gelecekte seçmek istedikleri mesleklere ilişkin algıları ile bu meslek çalışanlarının kişisel özellikleri, ne işlerle uğraştıkları hakkında ve hangi meslek dalları ile yakınlık gösterdikleri hakkında zihinlerinde oluşan algıların belirlenmesi amaçlanmıştır.

\section{2. Çalışma Grubu}

Bu araştırmanın çalışma grubunu 2016-2017 eğitim öğretim yılında Bitlis İli Adilcevaz ilçesinde bulunan bir ortaokulda öğrenim görmekte olan 53 altıncı sınıf öğrencisi $(\mathrm{NK} 1 \mathrm{Z}=26$, NErkek=27) oluşturmaktadır. Çalışma grubunun belirlenmesinde uygun örnekleme yöntemi kullanılmıştır. Uygun örnekleme yöntemi, kolay erişilebilirlik, coğrafi yakınlık, belirli bir zamandaki kullanılabilirlik veya katılma isteği gibi bazı elverişli kriterleri karşılayan hedef nüfusun üyelerinin çalışmanın amaçları için dahil edildiği seçkisiz olmayan örnekleme yöntemlerinden biridir (Dornyei, 2007). Bu araştırmada çalışma grubunun araştırmacılara yakınlığından ve kolay erişilebilirliğinden dolayı çalışma grubunun belirlenmesinde uygun örnekleme yöntemi kullanılmıştır. Çalışma grubunda yer alan öğrencilerin cinsiyete göre dağılımları Tablo 1'de sunulmuştur.

\section{Tablo 1.}

Çalışma Grubunun Cinsiyete Göre Dağılımı

\begin{tabular}{llc}
\hline Cinsiyet & $\mathbf{N}$ & Yüzde (\%) \\
\hline Kız & 26 & 49.06 \\
\hline Erkek & 27 & 50.94 \\
\hline TOPLAM & 53 & 100 \\
\hline
\end{tabular}


Gelecekte seçmek istedikleri mesleklere ilişkin öğrenci görüşleri

\subsection{Veri Toplama Aracı}

Araştırmada veri toplama aracı olarak dört açık uçlu sorudan oluşan bir form kullanılmıştır. $\mathrm{Bu}$ form hazırlanırken ilk önce konuyla ilgili literatür taraması yapılmıştır (Anılan, Çemrek ve Anagün, 2008; Aktın, 2017; Can ve Taylı; 2014). Bu literatür taramasından toplanan bilgiler çerçevesinde öğrencilerin konuyla ilgili düşüncelerini tespit etmek amaciyla taslak bir form oluşturulmuştur.

$\mathrm{Bu}$ formda yer alan sorular sırasıyla şu şekildedir:

1) Hayalinizdeki meslek nedir?

2) Hayalinizdeki mesleği tanımlayınız.

3) Seçtiğiniz meslekte çalışan biri ne tür işler yapar?

4) Seçtiğiniz meslekte çalışan kişinin kişisel özelliklerini yazınız.

5) Bu meslek dalı hangi mesleklere yakınlık göstermektedir?

Taslak formda beş açık uçlu soruya yer verilmiştir. Araştırmacılar tarafindan hazırlanan bu form anlaşılmayan noktaları belirtmeleri ve öneriler sunmaları açısından uzman ve akran incelemesine sunulmuştur. İki fen eğitimcisi ve aynı yaşta diğer şubede yer alan ve uygun örnekleme yöntemi ile seçilen 25 öğrenciden elde edilen dönütler neticesinde formda çeşitli düzenlemeler yapılmıştır. Başlangıçta beş soru olarak hazırlanan taslak formdaki 2. ve 3. sorunun birleştirilmesi ve bazı sözcüklerin değiştirilmesi önerilmiştir. Yapılan düzeltmeler neticesinde formun nihai halinde yer alan dört açık uçlu soru sırasıyla aşağıdaki şekliyle belirlenmiştir.

Gelecekte seçmek istediğiniz meslek nedir?

Gelecekte seçmek istediğiniz mesleği tanımlayınız. Bu meslekte çalışan biri ne tür işler yapar?

Seçtiğiniz bu meslekte çalışan birinin kişisel özelliklerini yazınız.

Bu meslek dalı hangi mesleklerle yakınlık göstermektedir?

$\mathrm{Bu}$ form, öğrencilerin ortama aşina olduğu sınıf ortamında verilen bir ders saati süre kapsamında öğrenciler tarafindan doldurulmuştur.

\subsection{Veri Analizi}

$\mathrm{Bu}$ araştırmada elde edilen verilerin analizinde içerik analizinden yararlanılmıştır. İçerik analizinde temel olarak yapılan işlem, birbirine benzeyen verileri belirli kavramlar ve temalar çerçevesinde bir araya getirmek ve bunları okuyucunun anlayabileceği bir biçimde düzenleyerek yorumlamaktır (Yıldırım ve Şimşek, 2013). Bu araştırmada da öncelikle her bir öğrencinin doldurduğu açık uçlu soru formu katılımcılara tekrar okutturulmuştur. Daha sonra öğrencilerin açık uçlu sorulara verdikleri yanıtlardan edilen veriler bilgisayar ortamına aktarılarak 53 sayfalık bir doküman oluşturulmuştur. Bu dokümanda yer alan her sorudan elde edilen verilerden kodlar ve temalar oluşturulmuş, ayrıca kodlara ilişkin sıklık frekansları, sıklığa bağlı yüzde ve temalara ilişkin yüzdeler belirlenmiştir. Tablolar içerisinde çalışma grubunda yer alan öğrenciler $1,2,3, \ldots \ldots \ldots . .53$ şeklinde simgelenmiştir. Ayrıca her bir tablonun devamında konuyla ilişkili öğrenci ifadelerinden alıntılar yapılmıştır. Öğrencilerin 
kendi yazmış oldukları yazılı dokümanlarından yapılan alıntılar resim formatında eklenerek metin içerisinde sunulmuştur. Ardından bulgular tanımlanarak yorumlar yapılmıştır.

Araştırmada tablolarda yer alan kod ve temaların araştırmacılar tarafindan nasıl oluşturulduğuna dair bir örnek aşağıda sunulmuştur. Örnek olarak öğrenciler ile yürütülen ön görüşsmede yer alan "Gelecekte seçmek istediğiniz mesleği tanımlayınız? Bu meslekte çalı̧̧an biri ne tür işler yapar?" sorusuna 41 kodlu öğrencinin verdiği cevap incelenmiştir.

41 kodlu öğrenci: "Ben İngilizce öğretmeni olmak isterim çünkü çocuklara İngilizce öğretmek onları hedeflerine ulaştırmak... (öğrencileri hedeflerine ulaştırma). Ben İngilizce'yi çok seviyorum. Ve sınıfta 1. olan benim. İngilizce değişik bir dil ve ben bunu öğrenmek büyük bir zevkle isterim. Seçtiğim meslekteki biri öğretmendir. Çocuklara bilgi öğretir... (öğretim). İngilizce- English."

$\mathrm{Bu}$ doğrultuda öğrencinin ifade ettiği cümle, kelime veya sözcük kümelerinden çıkarılan anlama bağlı olarak parantez içinde yer alan kısımlar araştırmacı tarafından ortaya çıkarılan kodlardır. Bunun yanında temaların oluşturulmasında kodların ortak noktaları, ifade ettiği anlamların kesişimleri etkili olmuştur. Dolayısıyla aynı örnek için temaların oluşturulması incelendiğinde; öğretmen olmak isteyen öğrencilerin öğretmenlik mesleğine ilişkin "meslek grubu özelliği" başlığı ve "eğitim alanındaki meslekler" temasına altında "öğrencileri hedeflerine ulaştırma" ve "öğretim" kodları verilmiştir.

\subsection{Geçerlik ve Güvenirlik}

Araştırmada geçerlik kapsamında, inandırııılık (iç geçerlik) için veri toplama aracının hazırlanmasında uzman incelemesi yapılmış, toplanan verilerin katılımcılar tarafından doğrulanması ve verilerin analizinde araştırmacı çeşitlemesi sağlanmıştır. Aktarılabilirliği (dış geçerlik) için ise; araştırmada yer alan araştırma deseni, araştırmaya katılan katılımcılar, veri toplama aracının hazırlanması ve ortaya çıkan bulgular ayrıntılı bir şekilde betimlenmiştir. Araştırmanın tutarlılığını (iç güvenirliğini) sağlamak için; katılımcıların açık uçlu sorulara verdiği cevaplardan alıntılar eklenmiştir. Teyit edilebilirliğini (dış güvenirliğini) sağlamak için ise; veri toplama aracının nasıl uygulandığı ve verilerin nasıl analiz edildiği detaylarıyla açıklamıştır. ve Şimşek (2013) iç güvenirliğin sağlanması için tutarlık incelemesi yapılmasını, dış güvenirliğin sağlanması için teyit incelemesi stratejilerinin kullanılmasını, iç geçerliğin sağlanması için uzman incelemesi, uzun süreli etkileşim sağlanması, derinliğe dayalı veri toplama faaliyeti, çeşitleme ve katılımcı teyidinin yapılması, dış geçerliğin sağlanması için ayrıntılı betimleme ve amaçlı örnekleme stratejilerinin kullanılması gerektiğini önermiştir. Bu bilgiler ışığında çalışma kapsamında geçerlik ve güvenirlik çalışmaları yürütülmüştür.

\section{BULGULAR}

Öğrencilerin "Gelecekte seçmek istediğiniz meslek nedir?" sorusuna verdikleri cevaplara ilişkin bulgular Tablo 2'de sunulmuştur. 
Gelecekte seçmek istedikleri mesleklere ilişkin öğrenci görüşleri

Tablo 2.

Öğrencilerin Gelecekte Seçmek İstedikleri Mesleklere İlişkin Bulgular

\begin{tabular}{|c|c|c|c|c|c|}
\hline $\begin{array}{l}\text { Meslek grubu } \\
\text { özelliği }\end{array}$ & Meslek & $\begin{array}{l}\text { Öğrenci } \\
\text { kodu }\end{array}$ & $\begin{array}{l}\text { Frekans } \\
\text { (f) }\end{array}$ & $\begin{array}{l}\text { Yüzde } \\
(\%)\end{array}$ & $\begin{array}{l}\text { Yüzde } \\
(\%)\end{array}$ \\
\hline \multirow{5}{*}{$\begin{array}{l}\text { El becerisine } \\
\text { dayalı meslekler }\end{array}$} & Ressam & 1 & 1 & 1.89 & \multirow[t]{5}{*}{11.32} \\
\hline & Moda tasarımcisı & 33 & 1 & 1.89 & \\
\hline & Mimar & 21,24 & 2 & 3.77 & \\
\hline & Mühendis & 27 & 1 & 1.89 & \\
\hline & Makine mühendisi & 52 & 1 & 1.89 & \\
\hline \multirow[t]{5}{*}{$\begin{array}{l}\text { Eğitim alanındaki } \\
\text { meslekler }\end{array}$} & $\begin{array}{l}\text { Fen bilimleri } \\
\text { öğretmeni }\end{array}$ & 4 & 1 & 1.89 & \multirow[t]{5}{*}{26.42} \\
\hline & İngilizce öğretmeni & 41 & 1 & 1.89 & \\
\hline & $\begin{array}{l}\text { Beden eğitimi } \\
\text { öğretmeni }\end{array}$ & 25,38 & 2 & 3.77 & \\
\hline & Matematik öğretmeni & 17 & 1 & 1.89 & \\
\hline & Öğretmen & $\begin{array}{l}11,12,22, \\
23,26,39, \\
42,46,48\end{array}$ & 9 & 16.98 & \\
\hline \multirow{2}{*}{$\begin{array}{l}\text { Güvenlik amacı } \\
\text { güden meslekler }\end{array}$} & Polis & $2,29,32,3$ & & 7.55 & \multirow[t]{2}{*}{-9.43} \\
\hline & Asker & 50 & 1 & 1.89 & \\
\hline \multirow{2}{*}{$\begin{array}{l}\text { Spor temelli } \\
\text { meslekler }\end{array}$} & Boksör & 3,28 & 2 & 3.77 & \multirow[t]{2}{*}{16.98} \\
\hline & Futbolcu & $\begin{array}{l}5,7,20,34, \\
36,37,44 \\
\end{array}$ & 7 & 13.21 & \\
\hline \multirow{5}{*}{$\begin{array}{l}\text { Sağlık alanı } \\
\text { meslekleri }\end{array}$} & Kalp cerrahı & 6 & 1 & 1.89 & \multirow[t]{5}{*}{24.53} \\
\hline & Hemşire & $\begin{array}{l}8,14,16, \\
31,51\end{array}$ & 5 & 9.43 & \\
\hline & Doktor & $\begin{array}{l}9,13,30, \\
40,47\end{array}$ & 5 & 9.43 & \\
\hline & Veteriner & 49 & 1 & 1.89 & \\
\hline & Beyin cerrahı & 53 & 1 & 1.89 & \\
\hline \multirow{2}{*}{$\begin{array}{l}\text { Araştırma amacı } \\
\text { güden meslekler }\end{array}$} & Astronot & 10,18 & 2 & 3.77 & \multirow[t]{2}{*}{7.55} \\
\hline & Bilim insanı & 15,45 & 2 & 3.77 & \\
\hline \multirow{2}{*}{$\begin{array}{l}\text { Yönetme } \\
\text { becerisine sahip } \\
\text { meslekler }\end{array}$} & Cumhurbaşkanı & 19 & 1 & 1.89 & \multirow[t]{2}{*}{3.77} \\
\hline & İş adamı & 43 & 1 & 1.89 & \\
\hline Toplam & & 53 & 53 & 100 & 100 \\
\hline
\end{tabular}

Tablo 2'de yer alan öğrencilerin cevapları incelendiğinde; gelecekte öğrencilerin çoğunlukla \%26.42'sinin eğitim alanındaki, \%24.53'ünün sağlık alanındaki ve \%16.98'inin spor alanındaki meslekleri tercih etmek istedikleri belirlenmiştir. Öğrencilerin \%3.77'sinin ise gelecekte yönetme becerisine sahip meslekleri tercih etmek istedikleri tespit edilmiştir. Bu bulgular doğrultusunda öğrencilerin büyük bir kısmının öğretmen, futbolcu, hemşire ve doktor olmak istedikleri, az sayıda öğrencinin ise cumhurbaşkanı ve iş adamı olmak istediği görülmüştür. Öğrencilerin ileride öğretmen, futbolcu, hemşire ve doktor olma nedenleri bu mesleklerin toplumdaki tercih edilme yoğunluğu ve mesleklerin statüleri ile açıklanabilir. Az sayıda öğrencinin 
cumhurbaşkanı ve iş adamı olmayı tercih etmelerinin sebebi ise; bu meslek gruplarını ulaşılamaz görmeleri olabilir.

Öğrencilerin "Gelecekte seçmek istediğiniz mesleği tanımlayınız? Bu meslekte çalışan biri ne tür işler yapar?" sorusuna ilişkin verdikleri cevaplar değerlendirilirken Tablo 3'teki meslek grupları dikkate alınmış ve her meslek grubu için ayrı tablolar oluşturulmuştur. Oluşturulan tablolar aşağıda sırasıyla sunulmuştur.

\section{Tablo 3.}

El Becerisine Dayalı Mesleklerin Yaptığı İşlere İlişkin Bulgular

\begin{tabular}{|c|c|c|c|c|c|c|}
\hline $\begin{array}{l}\text { Meslek } \\
\text { grubu } \\
\text { özelliği }\end{array}$ & Meslek & Yaptığı iş & $\begin{array}{l}\text { Öğrencinin } \\
\text { kodu }\end{array}$ & $\begin{array}{c}\text { Sıklık } \\
\text { Frekansı } \\
\text { (f) }\end{array}$ & $\begin{array}{c}\text { Sıklığa } \\
\text { bağlı } \\
\text { yüzde } \\
(\%)\end{array}$ & $\begin{array}{c}\text { Yüzde } \\
(\%)\end{array}$ \\
\hline \multirow{10}{*}{$\begin{array}{l}\text { El becerisin } \\
\text { dayalı } \\
\text { meslekler }\end{array}$} & Ressam & Resim çizme & 1 & 1 & 8.33 & 16.67 \\
\hline & & $\begin{array}{l}\text { Ürün } \\
\text { sergileme }\end{array}$ & 1 & 1 & 8.33 & \\
\hline & $\begin{array}{l}\text { Moda } \\
\text { tasarımcıs1 }\end{array}$ & $\begin{array}{l}\text { Renk uyumu } \\
\text { sağlama }\end{array}$ & 33 & 1 & 8.33 & 25.00 \\
\hline & & $\begin{array}{l}\text { Elbise } \\
\text { tasarlama }\end{array}$ & 33 & 1 & 8.33 & \\
\hline & & $\begin{array}{l}\text { Ürünlerini } \\
\text { sunma }\end{array}$ & 33 & 1 & 8.33 & \\
\hline & Mimar & $\begin{array}{l}\text { Görsel işler } \\
\text { yapma }\end{array}$ & 21 & 1 & 8.33 & 41.67 \\
\hline & & $\begin{array}{l}\text { Sayısal işler } \\
\text { yapma }\end{array}$ & 21,24 & 2 & 16.67 & \\
\hline & & $\begin{array}{l}\text { Tasarım } \\
\text { yapma }\end{array}$ & 21,24 & 2 & 16.67 & \\
\hline & Mühendis & $\begin{array}{l}\text { Yeni inşa } \\
\text { yapma }\end{array}$ & 27 & 1 & 8.33 & 8.33 \\
\hline & $\begin{array}{l}\text { Makine } \\
\text { mühendisi }\end{array}$ & İcat yapma & 52 & 1 & 8.33 & 8.33 \\
\hline Toplam & & & 6 & $12 *$ & 100 & 100 \\
\hline
\end{tabular}

*Öğrencilerin ifadelerinin sıklık frekansıdır.

Tablo 3 incelendiğinde gelecekte el becerisine dayalı meslekleri seçmek isteyen öğrenciler (f:6) bir ressamın \%8.33 sıklıkla resim çizdiğini ve \%8.33 sıklıkla bu ürünleri sergilediğini, moda tasarımcısının \%8.33 sıklıkla ürünlerinde renk uyumu sağladığını, \%8.33 sıklıkla elbise tasarladığı ve \%8.33 sıklıkla bu ürünleri sunduğunu, bir mimarın \%8.33 sıklıkla görsel, \%16.67 sıklıkla sayısal işlerle uğraştıklarını ve \%16.67 sıklıkla farklı tasarımlar yaptığını, \%8.33 sıklıkla mühendisin inşa yaptığını, mühendisin ise \%8.33 sıklıkla icat yaptığını belirtmişlerdir. Bu gruba ait meslek dallarını seçmek isteyen öğrencilerin geneli bu mesleklerde yer alan kişilerin ürün oluşturma ve bu ürünleri sunma odaklı görevlerde yer aldığını belirtmiştir.

El becerisine dayalı mesleklerden ressamın yaptığı işe ilişkin 1 numaralı öğrencinin görüşü aşağıda sunulmuştur: 


$$
\begin{aligned}
& \text { Resim cizen ciadigi } \\
& \text { resimtent serngikemekfadin. }
\end{aligned}
$$

Tablo 4.

\begin{tabular}{|c|c|c|c|c|c|}
\hline $\begin{array}{l}\text { Meslek } \\
\text { grubu } \\
\text { özelliği }\end{array}$ & Meslek & Yaptığı iş & $\begin{array}{l}\text { Öğrencinin } \\
\text { kodu }\end{array}$ & $\begin{array}{c}\text { Siklık } \\
\text { Frekansı } \\
\text { (f) }\end{array}$ & $\begin{array}{c}\text { Sıklığa } \\
\text { bağlı } \\
\text { yüzde } \\
(\%)\end{array}$ \\
\hline \multirow{10}{*}{$\begin{array}{l}\text { Eğitim } \\
\text { alanındaki } \\
\text { meslekler }\end{array}$} & \multirow[t]{10}{*}{ Öğretmen } & $\begin{array}{l}\text { Ülkenin istikbalini } \\
\text { geliştirme }\end{array}$ & 4 & 1 & 5.00 \\
\hline & & Eğitim vermek & 4 & 1 & 5.00 \\
\hline & & $\begin{array}{l}\text { Öğrencileri } \\
\text { hedeflerine ulaştırma }\end{array}$ & 41 & 1 & 5.00 \\
\hline & & Spor yapma/yaptırma & $25,38,48$ & 3 & 15.00 \\
\hline & & $\begin{array}{l}\text { Eğitimin gelişmesini } \\
\text { sağlama }\end{array}$ & 17 & 1 & 5.00 \\
\hline & & Öğretim & $\begin{array}{l}11,12,17,22, \\
23,26,39,41, \\
46\end{array}$ & 9 & 45.00 \\
\hline & & Kitap okutma & 39 & 1 & 5.00 \\
\hline & & Ders çalıştırma & 11 & 1 & 5.00 \\
\hline & & Yazı yazdırma & 39 & 1 & 5.00 \\
\hline & & Çocuklarla ilgilenme & 42 & 1 & 5.00 \\
\hline Toplam & & & 13 & $20 *$ & 100 \\
\hline
\end{tabular}

Ĕ̆itim Alanındaki Mesleklerin Yaptı̆̆ İşlere İlişkin Bulgular

*Öğrencilerin ifadelerinin sıklık frekansıdır.

Tablo 4 incelendiğinde gelecekte eğitim alanındaki meslekleri seçmek isteyen öğrencilerin (f:13) tamamı bu meslekler içinden öğretmenlik mesleğini vurgulamıştır. Öğrenciler, öğretmenlerin görevini $\% 45.00$ siklıkla öğretim yapma, \%5.00 sıklıkla ülkenin istikbalini ve \%5.00 sıklıkla eğitimi geliştirme olarak belirtmişlerdir. Öğrenciler ayrıca \%15.00 sıklıkla öğretmenlerin spor yapması/yaptırması gerektiğini belirtmişlerdir. Öğrencilerin bu düşüncesi beden öğretmenliği branşını göz önünde bulundurmalarından kaynaklandığı düşünülmektedir. Bu gruba ait meslek dallarını seçmek isteyen öğrenciler çoğunlukla bu mesleklerde yer alan kişilerin bilgi verme görevinde yer aldığını belirtmiştir.

Eğitim alanındaki mesleklerden öğretmenin yaptığı işe ilişkin 4 numaralı öğrencinin görüşü aşağıda sunulmuştur:

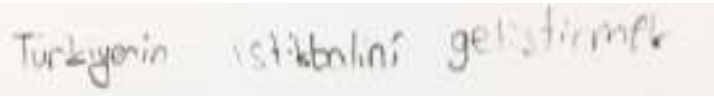

Yukarıdaki öğrenci görüşü gibi eğitim alanındaki mesleklerden öğretmenin yaptığı işe ilişkin 17 numaralı öğrencinin görüşü aşağıda sunulmuştur:

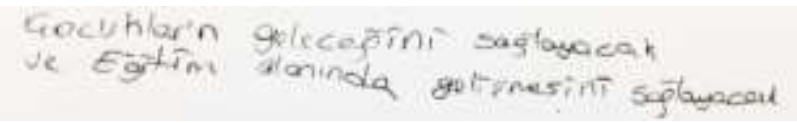


Tablo 5.

Güvenlik Amacı Güden Mesleklerin Yaptığ İşlere İlişkin Bulgular

\begin{tabular}{|c|c|c|c|c|c|c|}
\hline $\begin{array}{l}\text { Meslek grubu } \\
\text { özelliği }\end{array}$ & Meslek & Yaptığı iş & $\begin{array}{l}\text { Öğrencinin } \\
\text { kodu }\end{array}$ & $\begin{array}{c}\text { Siklık } \\
\text { Frekansı } \\
\text { (f) }\end{array}$ & $\begin{array}{c}\text { Sıklığa } \\
\text { bağlı } \\
\text { yüzde } \\
(\%)\end{array}$ & $\begin{array}{c}\text { Yüzde } \\
(\%)\end{array}$ \\
\hline \multirow{3}{*}{$\begin{array}{l}\text { Güvenlik } \\
\text { amacı güden } \\
\text { meslekler }\end{array}$} & Polis & $\begin{array}{l}\text { Vatanı } \\
\text { kurtarma }\end{array}$ & 2 & 1 & 16.67 & \multirow[t]{2}{*}{83.34} \\
\hline & & $\begin{array}{l}\text { Toplum } \\
\text { huzurunu } \\
\text { sağlama } \\
\end{array}$ & $2,29,32,35$ & 4 & 66.67 & \\
\hline & Asker & $\begin{array}{l}\text { Vatanı } \\
\text { koruma }\end{array}$ & 50 & 1 & 16.67 & 16.67 \\
\hline Toplam & & & 5 & $6^{*}$ & 100 & 100 \\
\hline
\end{tabular}

*Öğrencilerin ifadelerinin sıklık frekansıdır.

Tablo 5 incelendiğinde gelecekte güvenlik amacı güden meslekleri seçmek isteyen ögrenciler (f:5) \%66.67 sıklıkla polislerin toplum huzurunu sağladıklarını ve polis ve askerlerin görevlerini \%16.67 sıklıkla vatanı kurtarma ve \%16.67 sıklıkla vatanı koruma olarak görevlerini doğru belirttikleri belirlenmiştir. $\mathrm{Bu}$ gruba ait meslek dallarını seçmek isteyen öğrenciler bu mesleklerde yer alan kişilerin toplum içerisinde huzur bozan durumları önleme görevinde yer aldığını belirtmiştir.

Güvenlik amacı güden mesleklerden polisin yaptı̆̆ı işe ilişkin 32 numaralı öğrencinin görüşü aşağıda sunulmuştur:

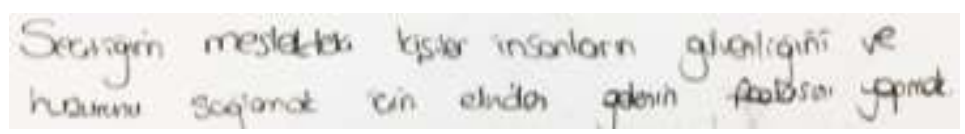

\begin{tabular}{|c|c|c|c|c|c|c|}
\hline \multicolumn{7}{|c|}{$\begin{array}{l}\text { Tablo 6. } \\
\text { Spor Temelli Mesleklerin Yaptığı İşlere İlişkin Bulgular }\end{array}$} \\
\hline $\begin{array}{l}\text { Meslek } \\
\text { grubu } \\
\text { özelliği }\end{array}$ & Meslek & Yaptığ 1 iş & $\begin{array}{l}\text { Öğrencinin } \\
\text { kodu }\end{array}$ & $\begin{array}{l}\text { Siklık } \\
\text { Frekansı } \\
\text { (f) }\end{array}$ & $\begin{array}{l}\text { Sıklığa } \\
\text { bağlı } \\
\text { yüzde (\%) }\end{array}$ & $\begin{array}{l}\text { Yüzde } \\
(\%)\end{array}$ \\
\hline \multirow{4}{*}{$\begin{array}{l}\text { Spor temelli } \\
\text { meslekler }\end{array}$} & Boksör & Dövüş yap & 3,28 & 2 & 20.00 & 30.00 \\
\hline & & $\begin{array}{l}\text { Vücut } \\
\text { geliștirme }\end{array}$ & 28 & 1 & 10.00 & \\
\hline & Futbolcu & $\begin{array}{l}\text { Takım } \\
\text { yönetme }\end{array}$ & 34 & 1 & 10.00 & 70.00 \\
\hline & & $\begin{array}{l}\text { Futbol } \\
\text { oynama }\end{array}$ & $\begin{array}{l}7,20,34,36, \\
37,44\end{array}$ & 6 & 60.00 & \\
\hline Toplam & & & 8 & $10 *$ & 100 & 100 \\
\hline
\end{tabular}

*Öğrencilerin ifadelerinin sıklık frekansıdır.

Tablo 6 incelendiğinde gelecekte spor temelli meslekleri seçmek isteyen öğrenciler (f:8) futbolcuların \%60.00 siklıkla futbol oynama, \%10.00 s1klıkla takım yönetme görevleri olduğunu, boksörlerin ise \%20.00 sıklıkla dövüş yapma ve $\% 10.00$ sıklıkla 
vücut geliştirme gibi görevleri olduğunu belirtmişlerdir. Bu gruba ait meslek dallarını seçmek isteyen öğrenciler bu mesleklerde yer alan kişilerin fizyolojik faaliyetlerde görev aldığını belirtmiştir.

Spor temelli mesleklerden futbolcuların yaptığı işe ilişkin 34 numaralı öğrencinin görüşü aşağıda sunulmuştur:

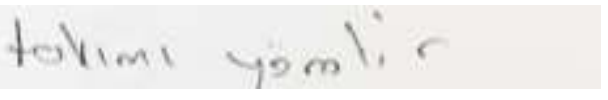

Tablo 7.

Sağllk Alanındaki Mesleklerin Yaptığı İşlere İlişkin Bulgular

\begin{tabular}{|c|c|c|c|c|c|c|}
\hline $\begin{array}{l}\text { Meslek } \\
\text { grubu } \\
\text { özelliği }\end{array}$ & Meslek & Yaptığı iş & $\begin{array}{l}\text { Öğrencinin } \\
\text { kodu }\end{array}$ & $\begin{array}{l}\text { S1kl1k } \\
\text { Frekans1 } \\
\text { (f) }\end{array}$ & $\begin{array}{c}\text { Siklığa } \\
\text { bağli } \\
\text { yüzde } \\
(\%)\end{array}$ & $\begin{array}{l}\text { Yüzde } \\
(\%)\end{array}$ \\
\hline Sağlık alanı & Kalp & Kalp nakli yapma & 6 & 1 & 3.57 & \\
\hline \multirow{17}{*}{ meslekleri } & cerrahı & Damar değiştirme & 6 & 1 & 3.57 & 10.71 \\
\hline & & Hayat kurtarma & 6 & 1 & 3.57 & \multirow{8}{*}{46.43} \\
\hline & Hemşire & $\begin{array}{l}\text { Hastaları } \\
\text { iyileştirme }\end{array}$ & 8 & 1 & 3.57 & \\
\hline & & Ĭğne yapma & $\begin{array}{c}8,14,16,31, \\
51\end{array}$ & 5 & 17.86 & \\
\hline & & Hastalara yardım & 14,16 & 2 & 7.14 & \\
\hline & & $\begin{array}{l}\text { İnsanların } \\
\text { sağlı̆̆ını } \\
\text { düşünme } \\
\end{array}$ & 31 & 1 & 3.57 & \\
\hline & & İlaç-reçete yazma & 31 & 1 & 3.57 & \\
\hline & & $\begin{array}{l}\text { Ameliyata } \\
\text { yardımcı olma }\end{array}$ & 31,51 & 2 & 7.14 & \\
\hline & & Doktora yardım & 51 & 1 & 3.57 & \\
\hline & $\overline{\text { Doktor }}$ & $\begin{array}{l}\text { Hastalara } \\
\text { yardımcı olma }\end{array}$ & $9,40,47$ & 3 & 10.71 & \multirow{5}{*}{32.14} \\
\hline & & $\begin{array}{l}\text { Hastaları } \\
\text { iyileştirme }\end{array}$ & 9,30 & 2 & 7.14 & \\
\hline & & İğne yapma & 13,40 & 2 & 7.14 & \\
\hline & & Ameliyat yapma & 13 & 1 & 3.57 & \\
\hline & & Hayat kurtarma & 47 & 1 & 3.57 & \\
\hline & Veteriner & $\begin{array}{l}\text { rHayvanlara aşı } \\
\text { yapma }\end{array}$ & 49 & 1 & 3.57 & 3.57 \\
\hline & $\begin{array}{l}\text { Beyin } \\
\text { cerrahı }\end{array}$ & $\begin{array}{l}\text { İnsan hayatını } \\
\text { kurtarma }\end{array}$ & 53 & 1 & 3.57 & \multirow[t]{2}{*}{7.14} \\
\hline & & Tedavi etme & 53 & 1 & 3.57 & \\
\hline Toplam & & & 13 & $28^{*}$ & 100 & 100 \\
\hline
\end{tabular}

*Öğrencilerin ifadelerinin sıklık frekansıdır.

Tablo 7 incelendiğinde gelecekte sağlık alanı meslekleri seçmek isteyen öğrenciler (f:13) \%17.86 sıklıkla hemşirelerin iğne yaptığını, \%10.71 sıklıkla doktorların hastalara 
yardım ettiğini, \%7.14 sıklıkla hastaları iyileştirdiğini ve \%7.14 sıklıkla iğne yaptığını belirtmişlerdir. Genellikle sağlık alanı mesleklerin görevlerine ilişkin açıklamalarda bulunmuşlardır. Hemşirelerin \%3.57 sıklıkla ilaç-reçete yazdığı belirtilmiştir. Belirtilen bu görev doktor göreviyle karıştırılmıştır. Bu gruba ait meslek dallarını seçmek isteyen öğrenciler bu mesleklerde yer alan kişilerin hastalıkları tedavi etmede görev aldığını belirtmiştir.

Sağlık alanı mesleklerinden kalp cerrahının yaptığı işe ilişkin 6 numaralı öğrencinin görüşü aşağıda sunulmuştur:

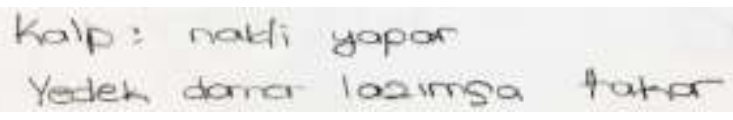

Yukarıdaki öğrenci görüşü gibi sağlık alanındaki mesleklerden hemşirenin yaptığı işe ilişkin 31 numaralı öğrencinin görüşü aşağıda sunulmuştur:

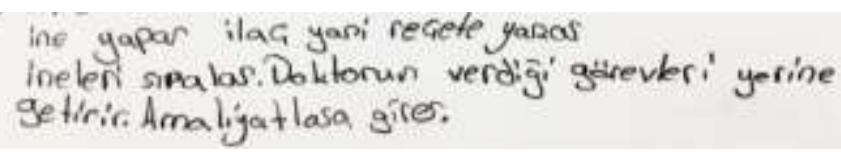

Tablo 8.

Araştırma Amacı Güden Mesleklerin Yaptığı İşlere İlişkin Bulgular

\begin{tabular}{|c|c|c|c|c|c|c|}
\hline $\begin{array}{l}\text { Meslek } \\
\text { grubu } \\
\text { özelliği }\end{array}$ & Meslek & Yaptığ 1 iş & $\begin{array}{l}\text { Öğrencinin } \\
\text { kodu }\end{array}$ & $\begin{array}{l}\text { Siklık } \\
\text { Frekansı } \\
\text { (f) }\end{array}$ & $\begin{array}{l}\text { Sıklığa } \\
\text { bağlı } \\
\text { yüzde } \\
(\%)\end{array}$ & $\begin{array}{l}\text { Yüzde } \\
(\%)\end{array}$ \\
\hline \multirow{3}{*}{$\begin{array}{l}\text { Araştırma } \\
\text { amacı güder } \\
\text { meslekler }\end{array}$} & Astronot & Uzaya uçma & 10,18 & 2 & 33.33 & \multirow[t]{2}{*}{66.67} \\
\hline & & $\begin{array}{l}\text { Gezegenleri } \\
\text { araştırma }\end{array}$ & 10,18 & 2 & 33.33 & \\
\hline & $\begin{array}{l}\text { Bilim } \\
\text { insanı }\end{array}$ & $\begin{array}{l}\text { Buluş, icat } \\
\text { yapma }\end{array}$ & 15,45 & 2 & 33.33 & 33.33 \\
\hline Toplam & & & 4 & $6^{*}$ & 100 & 100 \\
\hline
\end{tabular}

*Öğrencilerin ifadelerinin sıklık frekansıdır.

Tablo 8 incelendiğinde gelecekte araştırma amacı güden meslekleri seçmek isteyen öğrenciler (f:4) astronotların \%33.33 sıklıkla uzaya uçtuğunu ve \%33.33 sıklıkla gezegenleri araştırdıklarını ifade ederken; bilim insanlarının \%33.33 sıklıkla buluş-icat yaptıklarını belirtmişlerdir. Ayrıca gizli bir ajanın yaptığı araştırmalarla toplum huzurunu sağlama gibi görevi olduğu belirtilmiştir. Bu gruba ait meslek dallarını seçmek isteyen öğrenciler bu mesleklerde yer alan kişilerin bilinmeyenleri keşfetme ve bilimsel çalışmalar yürütmede görev aldığını belirtmiştir.

Araştırma amacı güden mesleklerden astronotun yaptığı işe ilişkin 18 numaralı öğrencinin görüşü aşağıda sunulmuştur:

$$
\text { Diaya cithar, gosegenter; arastirir. }
$$

Yukarıdaki öğrenci görüşü gibi araştırma amacı güden mesleklerden bilim insanının yaptığı işe ilişkin 15 numaralı öğrencinin görüşü aşağıda sunulmuştur: 


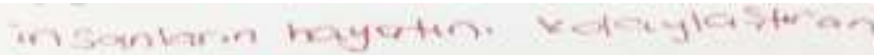

butwolatgonat

Tablo 9.

Yönetme Becerisine Sahip Mesleklerin Yaptı̆̆ İşlere İlişskin Bulgular

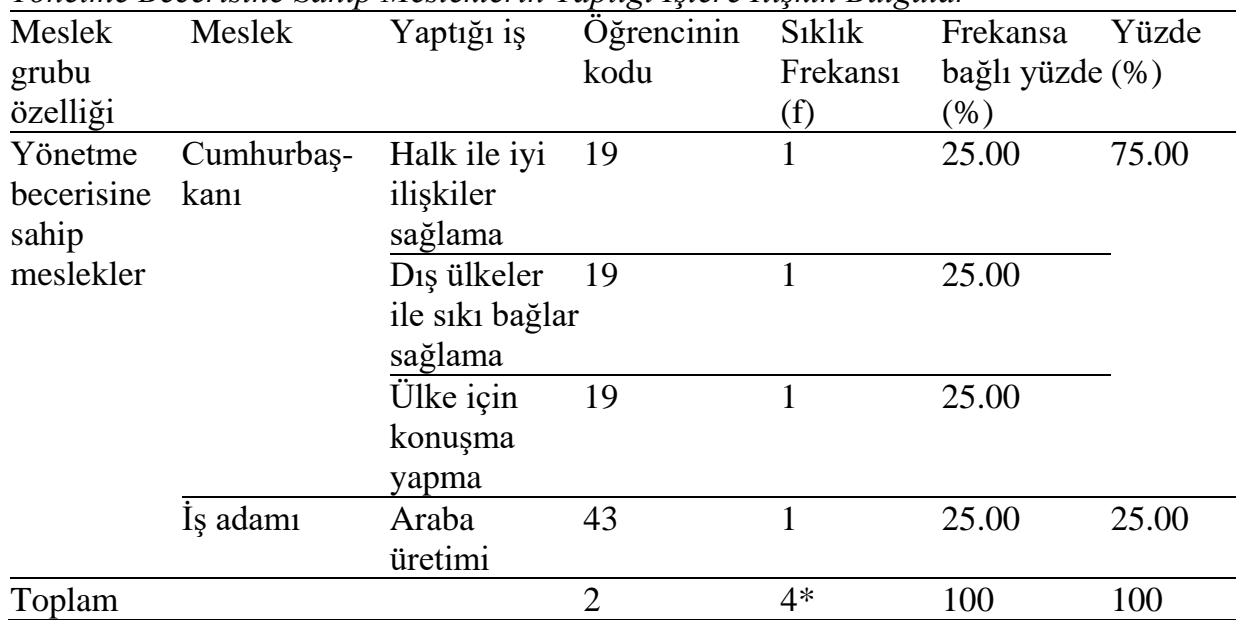

*Öğrencilerin ifadelerinin sıklık frekansıdır.

Tablo 9'a göre gelecekte yönetme becerisine sahip meslekleri seçmek isteyen öğrenciler (f:2) \%25.00 sıklıkla cumhurbaşkanının halkı tanıma, \%25.00 sıklıkla dış ülkeler ile bağlantılar kurma, \%25.00 sıklıkla ülke için konuşma yapma gibi görevlerinin olduğunu, \%25.00 sıklıkla bir iş adamının araba üretimi yaptığını belirtmiştir. Bu gruba ait meslek dallarını seçmek isteyen öğrenciler bu mesleklerde yer alan kişilerin ülke içi ve dışında olumlu iletişim ve etkileşim faaliyetleri sağlama konumunda görev aldığını belirtmiştir.

Yönetme becerisine sahip mesleklerden cumhurbaşkanının yaptığı işe ilişkin 19 numaralı öğrencinin görüşü aşağıda sunulmuştur:

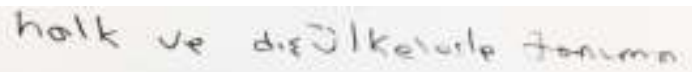

Öğrencilerin "Seçtiğiniz bu meslekte çalışan birinin kişisel özelliklerini yazınız." sorusuna ilişkin verdikleri cevaplar değerlendirilirken Tablo 2'deki meslek grupları dikkate alınmış ve oluşturulan tablolar aşağıda sırasıyla sunulmuştur. 
Muhammed Doğukan BALÇIN, Melike YAVUZ TOPALOĞLU

Tablo 10.

El Becerisine Dayalı Mesleklerde Çalışan Birinin Kişisel Özellikleri

\begin{tabular}{|c|c|c|c|c|c|c|}
\hline $\begin{array}{l}\text { Meslek } \\
\text { grubu } \\
\text { özelliği }\end{array}$ & Tema & Kod & $\begin{array}{l}\text { Öğrencinin } \\
\text { kodu }\end{array}$ & $\begin{array}{l}\text { Siklık } \\
\text { Frekansı } \\
\text { (f) }\end{array}$ & $\begin{array}{l}\text { Siklığa } \\
\text { bağl1 } \\
\text { yüzde } \\
(\%)\end{array}$ & $\begin{array}{l}\text { Yüzde } \\
(\%)\end{array}$ \\
\hline \multirow{8}{*}{$\begin{array}{l}\text { El } \\
\text { becerisine } \\
\text { dayalı } \\
\text { meslekler }\end{array}$} & Bilişsel & Yaratıcı & $1,33,52$ & 3 & 20.00 & \multirow[t]{4}{*}{73.33} \\
\hline & özellik & Çalıșkan & $1,21,33$ & 3 & 20.00 & \\
\hline & & Zeki & $1,21,27,52$ & 4 & 26.67 & \\
\hline & & Bilgili & 27 & 1 & 6.67 & \\
\hline & $\begin{array}{l}\text { Psikomotor } \\
\text { özellik }\end{array}$ & Becerikli & 33 & 1 & 6.67 & 6.67 \\
\hline & $\begin{array}{l}\text { Duyuşsal } \\
\text { özellik }\end{array}$ & $\begin{array}{l}\text { Sorumluluk } \\
\text { sahibi }\end{array}$ & 21 & 1 & 6.67 & \multirow[t]{3}{*}{20.00} \\
\hline & & $\begin{array}{l}\text { Güven veren } \\
\text { biri }\end{array}$ & 21 & 1 & 6.67 & \\
\hline & & $\begin{array}{l}\text { Düzenli ortam } \\
\text { seven }\end{array}$ & 24 & 1 & 6.67 & \\
\hline Toplam & & & 6 & $15^{*}$ & 100 & 100 \\
\hline
\end{tabular}

*Öğrencilerin ifadelerinin sıklık frekansıdır.

Tablo 10 incelendiğinde öğrenciler el becerisine dayalı mesleklerde çalışan birinin $\% 73.33$ s1klıkla bilişsel özelliklerinden, \%6.67 s1klıkla psikomotor özelliklerinden, \%20.00 sıklıkla duyuşsal özelliklerinden bahsetmişlerdir. Öğrenciler el becerisine dayalı mesleklerde çalışan birinin \%26.67 sıklıkla zeki, \%20.00 sıklıkla yaratıcı, \%20.00 sıklıkla çalışkan olma gibi kişisel özelliklerinin olduğunu belirtmişlerdir. Öğrencilerin çoğunluğu; el becerisine sahip mesleklerde çalışan bireylerin psikomotor özelliklerinden çok bilişsel özelliklerini vurgulamıştır.

El becerisine dayalı mesleğe sahip olan birinin kişisel özelliklerinden 'bilişsel özellik' temasının 'yaratıcı', 'çalışkan' kodlarını ve 'psikomotor özellik' temasının 'becerikli' kodunu içeren 33 numaralı öğrencinin görüşü aşağıda sunulmuştur:

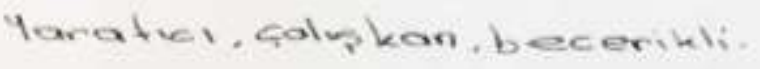

Yukarıdaki öğrenci görüşü gibi el becerisine dayalı mesleğe sahip olan birinin kişisel özelliklerinden 'bilişsel özellik' temasının 'zeki', 'çalışkan' kodlarını ve 'duyuşsal özellik' temasının 'sorumluluk sahibi', 'güven veren biri’ kodlarını içeren 21 numaralı öğrencinin görüşü aşağıda sunulmuştur:

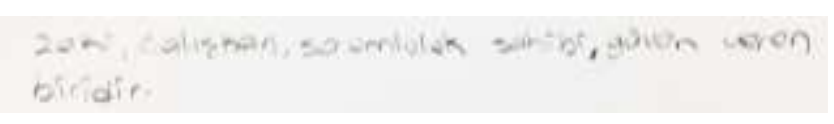


Gelecekte seçmek istedikleri mesleklere ilişkin öğrenci görüşleri

\begin{tabular}{|c|c|c|c|c|c|c|}
\hline \multicolumn{7}{|c|}{$\begin{array}{l}\text { Tablo } 11 . \\
\text { Eğitim Alanındaki Mesleklerde Çalışan Birinin Kişisel Özellikleri }\end{array}$} \\
\hline $\begin{array}{l}\text { Meslek } \\
\text { grubu } \\
\text { özelliği }\end{array}$ & Tema & Kod & $\begin{array}{l}\text { Öğrencinin } \\
\text { kodu }\end{array}$ & $\begin{array}{l}\text { S1klik } \\
\text { Frekansı } \\
\text { (f) }\end{array}$ & $\begin{array}{l}\text { Siklığa } \\
\text { bağlı } \\
\text { yüzde (\%) }\end{array}$ & $\begin{array}{l}\text { Yüzde } \\
(\%)\end{array}$ \\
\hline \multirow{13}{*}{$\begin{array}{l}\text { Eğitim } \\
\text { alanındaki } \\
\text { meslekler }\end{array}$} & Bilişsel & Çalışkan & $11,17,42,46$ & 4 & 19.05 & 33.33 \\
\hline & özellik & Bilgili & 41 & 1 & 4.76 & \\
\hline & & Düşünceli & 17 & 1 & 4.76 & \\
\hline & & Zeki & 17 & 1 & 4.76 & \\
\hline & $\begin{array}{l}\text { Duyuşsal } \\
\text { özellik }\end{array}$ & $\begin{array}{l}\text { Cana } \\
\text { yakınlık }\end{array}$ & 39,41 & 2 & 9.52 & 57.14 \\
\hline & & Zarif & 25 & 1 & 4.76 & \\
\hline & & Sakin & 25 & 1 & 4.76 & \\
\hline & & Dürüst & 11,38 & 2 & 9.52 & \\
\hline & & $\begin{array}{l}\text { Kitap } \\
\text { okumayı } \\
\text { sevme }\end{array}$ & 22 & 1 & 4.76 & \\
\hline & & Güvenilir & 39 & 1 & 4.76 & \\
\hline & & $\begin{array}{l}\text { Çocukları } \\
\text { sevme }\end{array}$ & 39 & 1 & 4.76 & \\
\hline & & $\begin{array}{l}\text { Mesleğini } \\
\text { sevme }\end{array}$ & $4,17,48$ & 3 & 14.29 & \\
\hline & $\begin{array}{l}\text { Psikomotor } \\
\text { özellik }\end{array}$ & $\begin{array}{l}\text { Spora bağl1 } \\
\text { olma }\end{array}$ & 25,38 & 2 & 9.52 & 9.52 \\
\hline Toplam & & & 14 & $21 *$ & 100 & 100 \\
\hline
\end{tabular}

*Öğrencilerin ifadelerinin sıklık frekansıdır.

Tablo 11 incelendiğinde öğrenciler eğitim alanındaki mesleklerde çalışan birinin \%57.14 sıklıkla duyuşsal özelliklerinden, \%33.33 sıklıkla bilişsel özelliklerinden, \%9.52 sıklıkla psikomotor özelliklerinden bahsetmişlerdir. Öğrenciler eğitim alanındaki mesleklerde çalışan birinin \%19.05 sıklıkla çalışkan, \%14.29 sıklıkla mesleğini sevme gibi kişisel özelliklerinin olduğunu belirtmişlerdir. Öğrencilerin çoğunluğu; eğitim alanındaki mesleklerde çalışan bireylerin duyuşsal bir takım özelliklerini vurgulamıştır.

Eğitim alanındaki mesleğe sahip olan birinin kişisel özelliklerinden 'duyuşsal özellik' temasının 'zarif', 'sakin' kodlarını içeren 25 numaralı öğrencinin görüşü aşağıda sunulmuştur:

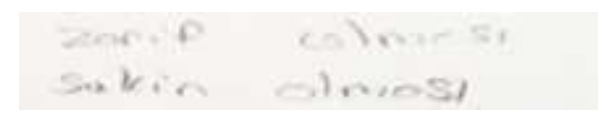

Yukarıdaki öğrenci görüşü gibi eğitim alanındaki mesleğe sahip olan birinin kişisel özelliklerinden 'bilişsel özellik' temasının 'çalışkan', 'düşünceli', 'zeki' kodlarını ve 'duyuşsal özellik' temasının 'mesleğini sevme' kodunu içeren 17 numaralı öğrencinin görüşü aşağıda sunulmuştur:

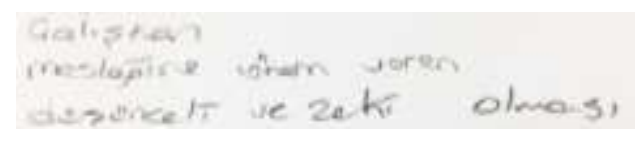


Muhammed Doğukan BALÇIN, Melike YAVUZ TOPALOĞLU

Tablo 12.

Güvenlik Amacı Güden Mesleklerde Çalışan Birinin Kişisel Özellikleri

\begin{tabular}{|c|c|c|c|c|c|c|}
\hline $\begin{array}{l}\text { Meslek } \\
\text { grubu } \\
\text { özelliği }\end{array}$ & Tema & Kod & $\begin{array}{l}\text { Öğrencinin } \\
\text { kodu }\end{array}$ & $\begin{array}{l}\text { Siklık } \\
\text { Frekansı } \\
\text { (f) }\end{array}$ & $\begin{array}{l}\text { Siklığa } \\
\text { bağl1 } \\
\text { yüzde } \\
(\%)\end{array}$ & $\begin{array}{l}\text { Yüzde } \\
(\%)\end{array}$ \\
\hline \multirow{7}{*}{$\begin{array}{l}\text { Güvenlik } \\
\text { amacı } \\
\text { güden } \\
\text { meslekler }\end{array}$} & $\begin{array}{l}\text { Bilişsel } \\
\text { özellik }\end{array}$ & Zeki & 2 & 1 & 14.29 & 14.29 \\
\hline & Duyuşsal & Sabirl1 & 29 & 1 & 14.29 & 71.43 \\
\hline & özellik & Adaletli & 32 & 1 & 14.29 & \\
\hline & & İyiliksever & 32 & 1 & 14.29 & \\
\hline & & Yardımsever & 35 & 1 & 14.29 & \\
\hline & & Vatansever & 50 & 1 & 14.29 & \\
\hline & $\begin{array}{l}\text { Psikomotor } \\
\text { özellik }\end{array}$ & Güçlü & 2 & 1 & 14.29 & 14.29 \\
\hline Toplam & & & 5 & $7 *$ & 100 & 100 \\
\hline
\end{tabular}

*Öğrencilerin ifadelerinin sıklık frekansıdır.

Tablo 12 incelendiğinde öğrenciler güvenlik amacı güden mesleklerde çalışan birinin \%57.14 sıklıkla bilişsel özelliklerinden, \%14.29 sıklıkla duyuşsal özelliklerinden, \%14.29 sıklıkla psikomotor özelliklerinden ve mesleği gereği \%14.29 sıklıkla vatana bağlı olmaları gerektiğinden bahsetmişlerdir. Öğrenciler güvenlik amacı güden mesleklerde çalışan birinin \%14.29 sıklıkla zeki, \%14.29 sıklıkla sabırlı, \%14.29 sıklıkla adaletli, \%14.29 sıklıkla vatansever olma gibi kişisel özelliklerinin olduğunu belirtmişlerdir. Öğrencilerin çoğunluğu; güvenlik amacı güden mesleklerde çalışan bireylerin bilişsel ve psikomotor özelliklerinden çok duyuşsal özelliklerini vurgulamıştır.

Güvenlik amacı güden mesleğe sahip olan birinin kişisel özelliklerinden 'bilişsel özellik' temasının 'zeki' kodunu ve 'psikomotor özellik' temasının 'güçlü' kodunu içeren 2 numaralı öğrencinin görüşü aşağıda sunulmuştur:

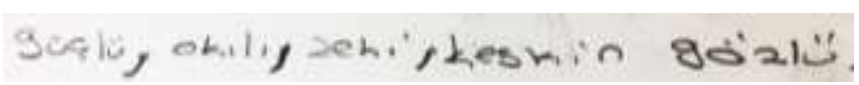

\section{Tablo 13.}

Spor Temelli Mesleklerde Çalışan Birinin Kişisel Özellikleri

\begin{tabular}{|c|c|c|c|c|c|c|}
\hline $\begin{array}{l}\text { Meslek } \\
\text { grubu } \\
\text { özelliği }\end{array}$ & Tema & Kod & $\begin{array}{l}\text { Öğrencinin } \\
\text { kodu }\end{array}$ & $\begin{array}{l}\text { Siklık } \\
\text { Frekansı } \\
\text { (f) }\end{array}$ & $\begin{array}{l}\text { Siklığa } \\
\text { bağlı } \\
\text { yüzde (\%) }\end{array}$ & $\begin{array}{l}\text { Yüzde } \\
(\%)\end{array}$ \\
\hline \multirow{6}{*}{$\begin{array}{l}\text { Spor } \\
\text { temelli } \\
\text { meslekles }\end{array}$} & \multirow{4}{*}{$\begin{array}{l}\text { Psikomotor } \\
\text { özellik }\end{array}$} & Yetenekli & $3,20,44$ & 3 & 37.50 & \multirow[t]{4}{*}{75.00} \\
\hline & & Güçlü & 28 & 1 & 12.50 & \\
\hline & & Hızli/Atik & 28 & 1 & 12.50 & \\
\hline & & Titiz & 5 & 1 & 12.50 & \\
\hline & Bilişsel özellik & Çalışkan & 34 & 1 & 12.50 & 12.50 \\
\hline & \multicolumn{2}{|c|}{ Duyuşsal özellik Saygılı } & 44 & 1 & 12.50 & 12.50 \\
\hline \multicolumn{3}{|l|}{ Toplam } & 6 & $8 *$ & 100 & 100 \\
\hline
\end{tabular}

*Öğrencilerin ifadelerinin sıklık frekansıdır. 
Tablo 13 incelendiğinde öğrenciler spor temelli mesleklerde çalışan birinin \%75.00 sıklıkla psikomotor özelliklerinden, \%12.50 sıklıkla duyuşsal özelliklerinden, \%12.50 sıklıkla bilişsel özelliklerinden bahsetmişlerdir. Öğrenciler spor temelli mesleklerde çalışan birinin mesleği gereği \%37.50 sıklıkla yetenekli, \%12.50 sıklıkla hızlı/atik, $\% 12.50$ sıklıkla işinde titiz olma gibi kişisel özelliklerinin olduğunu belirtmişlerdir. Öğrencilerin çoğunluğu; spor temelli mesleklerde çalışan bireylerin psikomotor bir takım özelliklerini vurgulamıştır.

Spor temelli mesleğe sahip olan birinin kişisel özelliklerinden 'psikomotor özellik' temasının 'güçlü', 'hızlı/atik' kodlarını içeren 28 numaralı öğrencinin görüşü aşağıda sunulmuştur:

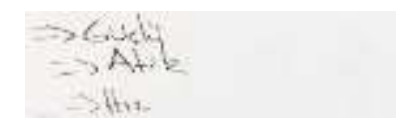

Tablo 14.

Să̆lık Alanındaki Mesleklerde Çalışan Birinin Kişisel Özellikleri

\begin{tabular}{|c|c|c|c|c|c|c|}
\hline $\begin{array}{l}\text { Meslek } \\
\text { grubu } \\
\text { özelliği }\end{array}$ & Tema & Kod & Öğrencinin kodu & $\begin{array}{l}\text { Siklık } \\
\text { Frekansı } \\
\text { (f) }\end{array}$ & $\begin{array}{l}\text { Siklığa } \\
\text { bağlı } \\
\text { yüzde } \\
(\%)\end{array}$ & $\begin{array}{l}\text { Yüzde } \\
(\%)\end{array}$ \\
\hline Sağlık alanı & Bilişsel & Zeki & $8,31,47,51,53$ & 5 & 21.74 & 34.79 \\
\hline \multirow[t]{12}{*}{ meslekleri } & özellik & Yaratıc1 & 6 & 1 & 4.35 & \\
\hline & & Çalışkan & 13,53 & 2 & 8.70 & \\
\hline & Duyuşsal & Dürüst & 31 & 1 & 4.35 & 60.87 \\
\hline & özellik & Neşeli & 13,49 & 2 & 8.70 & \\
\hline & & Sayg1lı & 8 & 1 & 4.35 & \\
\hline & & Sessiz & 31 & 1 & 4.35 & \\
\hline & & $\begin{array}{l}\text { Sorumluluk } \\
\text { sahibi olma }\end{array}$ & 47 & 1 & 4.35 & \\
\hline & & Yardımsever & $31,40,51$ & 3 & 13.04 & \\
\hline & & $\begin{array}{l}\text { Düşünceli } \\
\text { olma }\end{array}$ & 53 & 1 & 4.35 & \\
\hline & & \multicolumn{2}{|c|}{$\begin{array}{l}\text { Kitap okumayı } 6 \\
\text { sever }\end{array}$} & 1 & 4.35 & \\
\hline & & $\begin{array}{l}\text { İşini severek } \\
\text { yapma }\end{array}$ & $8,14,30$ & 3 & 13.04 & \\
\hline & $\begin{array}{l}\text { Psikomotor } \\
\text { özellik }\end{array}$ & Titiz & 14 & 1 & 4.35 & 4.35 \\
\hline Toplam & & & 13 & $23 *$ & 100 & 100 \\
\hline
\end{tabular}

*Öğrencilerin ifadelerinin sıklık frekansıdır.

Tablo 14 incelendiğinde öğrenciler sağlık alanındaki mesleklerde çalışan birinin \%43.48 sıklıkla duyuşsal özelliklerinden, \%34.79 sıklıkla bilişsel özelliklerinden, \%21.74 sıklıkla psikomotor özelliklerinden bahsetmişlerdir. Öğrenciler sağlık alanındaki mesleklerde çalışan birinin \%21.74 sıklıkla zeki, \%13.04 sıklıkla yardımsever, \%13.04 sıklıkla işini severek yapma gibi kişisel özelliklerinin olduğunu 
belirtmişlerdir. Öğrencilerin çoğunluğu; sağlık alanındaki mesleklerde çalışan bireylerin daha çok duyuşsal özelliklerini vurgulamıştır.

Sağlık alanı mesleğine sahip olan birinin kişisel özelliklerinden 'bilişsel özellik' temasının 'zeki' kodunu ve 'duyuşsal özellik' temasının 'işini severek yapma', 'saygılı' kodlarını içeren 8 numaralı öğrencinin görüşü aşağıda sunulmuştur:

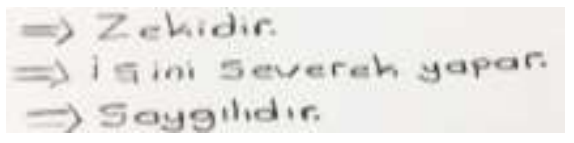

Yukarıdaki öğrenci görüşü gibi sağlık alanı mesleğine sahip olan birinin kişisel özelliklerinden 'bilişsel özellik' temasının 'zeki' kodunu ve 'duyuşsal özellik' temasının 'sorumluluk sahibi olma' kodunu içeren 47 numaralı öğrencinin görüşü aşağıda sunulmuştur:

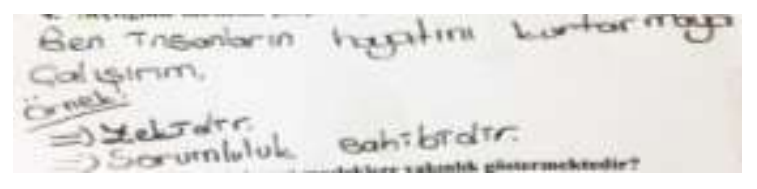

Tablo 15.

Araştırma Amacı Güden Mesleklerde Çalışan Birinin Kişisel Özellikleri

\begin{tabular}{|c|c|c|c|c|c|c|}
\hline $\begin{array}{l}\text { Meslek } \\
\text { grubu } \\
\text { özelliği }\end{array}$ & Tema & Kod & $\begin{array}{l}\text { Öğrencinin } \\
\text { kodu }\end{array}$ & $\begin{array}{l}\text { Siklik } \\
\text { (n) }\end{array}$ & $\begin{array}{l}\text { Siklı̆̆a } \\
\text { bağlı } \\
\text { yüzde (\%) }\end{array}$ & $\begin{array}{l}\text { Yüzde } \\
(\%)\end{array}$ \\
\hline $\begin{array}{l}\text { Araştırma } \\
\text { amacı güdeı }\end{array}$ & $\begin{array}{l}\text { Duyuşsal } \\
\text { özellik }\end{array}$ & $\begin{array}{l}\text { Sessiz ortam } \\
\text { sevme }\end{array}$ & 10 & 1 & 11.11 & 66.66 \\
\hline \multirow[t]{7}{*}{ meslekler } & & Özgüvenli & 18 & 1 & 11.11 & \\
\hline & & $\begin{array}{l}\text { Güven veren } \\
\text { biri olma }\end{array}$ & 18 & 1 & 11.11 & \\
\hline & & Yardimsever & 18 & 1 & 11.11 & \\
\hline & & Sabirl1 & 15 & 1 & 11.11 & \\
\hline & & $\begin{array}{l}\text { Başkalarını } \\
\text { düşünen biri } \\
\text { olma }\end{array}$ & 15 & 1 & 11.11 & \\
\hline & Bilişsel & $\underline{\text { Zeki }}$ & 18 & 1 & 11.11 & 33.33 \\
\hline & özellik & Çalışkan & 15,45 & 2 & 22.22 & \\
\hline Toplam & & & 4 & $9 *$ & 100 & 100 \\
\hline
\end{tabular}

*Öğrencilerin ifadelerinin sıklık frekansıdır.

Tablo 15 incelendiğinde öğrenciler araştırma amacı güden mesleklerde çalışan birinin \%66.66 sıklıkla duyuşsal özelliklerinden, \%33.33 sıklıkla bilişsel özelliklerinden bahsetmişlerdir. Öğrenciler araştırma amacı güden mesleklerde çalışan birinin \%22.22 sıklıkla zeki, \%13.04 sıklıkla yardımsever, \%11.11 sıklıkla özgüvenli olma gibi kişisel özelliklerinin olduğunu belirtmişlerdir. Öğrencilerin çoğunluğu; araştırma amacı güden mesleklerde çalışan bireylerin bilişsel özelliklerinden çok duyuşsal bir takım özelliklerini vurgulamıştır. 
Araştırma amacı güden mesleğe sahip olan birinin kişisel özelliklerinden 'bilişsel özellik' temasının 'çalışkan' kodunu ve 'duyuşsal özellik' temasının 'başkalarını düşünen biri olma', 'sabırlı' kodlarını içeren 15 numaralı öğrencinin görüşü aşağıda sunulmuştur:

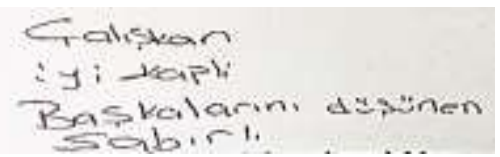

Tablo 16.

Yönetme Becerisine Sahip Mesleklerde Çalışan Birinin Kişisel Özellikleri

\begin{tabular}{|c|c|c|c|c|c|c|}
\hline $\begin{array}{l}\text { Meslek } \\
\text { grubu } \\
\text { özelliği }\end{array}$ & Tema & Kod & Öğrencinin kodu & $\begin{array}{l}\text { Siklik } \\
\text { Frekans1 } \\
\text { (f) }\end{array}$ & $\begin{array}{l}\text { Siklığa } \\
\text { bağll } \\
\text { yüzde (\%) }\end{array}$ & $\begin{array}{l}\text { Yüzde } \\
(\%)\end{array}$ \\
\hline \multirow{5}{*}{$\begin{array}{l}\text { Yönetme } \\
\text { becerisine } \\
\text { sahip } \\
\text { meslekler }\end{array}$} & \multirow{3}{*}{$\begin{array}{l}\text { Duyuşsal } \\
\text { özellik }\end{array}$} & Duyarlı & 19 & 1 & 16.67 & \multirow[t]{3}{*}{50.00} \\
\hline & & Duygusal & 43 & 1 & 16.67 & \\
\hline & & Sinirli & 43 & 1 & 16.67 & \\
\hline & Bilişsel & Zeki & 19 & 1 & 16.67 & 50.00 \\
\hline & özellik & Çalışkan & 19,43 & 2 & 33.33 & \\
\hline Toplam & & & 2 & $6^{*}$ & 100 & 100 \\
\hline
\end{tabular}

*Öğrencilerin ifadelerinin sıklık frekansıdır.

Tablo 16 incelendiğinde öğrenciler yönetme becerisine sahip mesleklerde çalışan birinin \%50..00 sıklıkla duyuşsal özelliklerinden, \%50.00 sıklıkla bilişsel özelliklerinden bahsetmişlerdir. Öğrenciler yönetme becerisine sahip mesleklerde çalışan birinin \%33.33 sıklıkla çalışkan, \%16.67 sıklıkla duyarlı olma gibi kişisel özelliklerinin olduğunu belirtmişlerdir. Öğrencilerin çoğunluğu; yönetme becerisine sahip mesleklerde çalışan bireylerin eşit oranda bilişsel ve duyuşsal bir takım özelliklerini vurgulamıştır.

Yönetme becerisine sahip mesleğe sahip olan birinin kişisel özelliklerinden 'bilişsel özellik' temasının 'çalı̧̧kan' kodunu ve 'duyuşsal özellik' temasının 'sinirli', 'duygusal' kodlarını içeren 43 numaralı öğrencinin görüşü aşağıda sunulmuştur:

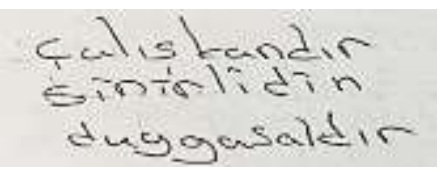

Öğrencilerin "Seçtiğiniz bu meslek dalı hangi meslek ile benzerlik göstermektedir?" sorusuna ilişkin verdikleri cevaplar Tablo 17'de sunulmuştur. 
Muhammed Doğukan BALÇIN, Melike YAVUZ TOPALOĞLU

\begin{tabular}{|c|c|c|c|c|}
\hline \multicolumn{5}{|c|}{$\begin{array}{l}\text { Tablo 17. } \\
\text { Öğrencilerin Gelecekte Seçmek İstedikleri Mesleklerin Benzerlik Gösterdiği Meslek Dalı ile } \\
\text { Illişkisi }\end{array}$} \\
\hline Meslek & Benzer olan meslek & Öğrenci kodu & $\begin{array}{l}\text { S1klik } \\
\text { Frekansı } \\
\text { (f) } \\
\end{array}$ & $\begin{array}{l}\text { S1klığa } \\
\text { bağlı yüzde } \\
(\%)\end{array}$ \\
\hline Ressam & Moda tasarımc1s1 & 1 & 1 & 2.17 \\
\hline & 33 & 1 & 2.17 \\
\hline \multicolumn{2}{|c|}{ Moda tasarımcisi $\frac{\text { Ressam }}{\text { Mimar }}$} & 33 & 1 & 2.17 \\
\hline \multicolumn{2}{|r|}{ Mühendis } & 21 & 1 & 2.17 \\
\hline \multicolumn{2}{|l|}{ Mühendis } & 27 & 1 & 2.17 \\
\hline \multicolumn{2}{|l|}{$\begin{array}{l}\text { Makine } \\
\text { mühendisi }\end{array}$} & 52 & 1 & 2.17 \\
\hline \multicolumn{2}{|l|}{$\begin{array}{l}\text { Fen bilimleri } \\
\text { öğretmeni }\end{array}$} & 4 & 1 & 2.17 \\
\hline \multirow{3}{*}{$\begin{array}{l}\text { İngilizce } \\
\text { öğretmeni }\end{array}$} & Doktor & 41 & 1 & 2.17 \\
\hline & Mühendis & 41 & 1 & 2.17 \\
\hline & Arkeolog & 41 & 1 & 2.17 \\
\hline \multirow{2}{*}{$\begin{array}{l}\text { Beden eğitimi } \\
\text { öğretmeni }\end{array}$} & Sağlık personeli & 25 & 1 & 2.17 \\
\hline & Sporcu & 38 & 1 & 2.17 \\
\hline $\begin{array}{l}\text { Matematik } \\
\text { öğretmeni }\end{array}$ & Mühendis & 17 & 1 & 2.17 \\
\hline \multirow[t]{3}{*}{ Öğretmen } & Müdür & 12 & 1 & 2.17 \\
\hline & Doktor & $12,22,23,39,42$ & 5 & 10.87 \\
\hline & Hâkim & 42 & 1 & 2.17 \\
\hline Polis & Asker & $2,29,32$ & 3 & 6.52 \\
\hline Asker & Özel harekât polisi & 50 & 1 & 2.17 \\
\hline \multirow{2}{*}{ Boksör } & Polis & 3 & 1 & 2.17 \\
\hline & Dövüş sporcuları & 28 & 1 & 2.17 \\
\hline \multirow[t]{2}{*}{ Futbolcu } & Basketbolcu & 5 & 1 & 2.17 \\
\hline & Beden eğitimi öğretmeni & 7,20 & 2 & 4.35 \\
\hline Kalp cerrahı & - & 6 & - & \\
\hline \multirow[t]{3}{*}{ Hemşire } & Fen bilimleri öğretmeni & 8 & 1 & 2.17 \\
\hline & Diş doktoru & 51 & 1 & 2.17 \\
\hline & Doktorluk & $14,16,31,51$ & 4 & 8.70 \\
\hline \multirow[t]{3}{*}{ Doktor } & Hemşire & 13 & 1 & 2.17 \\
\hline & Bilim insanı & 30 & 1 & 2.17 \\
\hline & Fen bilimleri öğretmeni & 47 & 1 & 2.17 \\
\hline Veteriner & Doktorluk & 49 & 1 & 2.17 \\
\hline \multirow{2}{*}{ Beyin cerrah1 } & - & 53 & - & \\
\hline & Pilot & 10 & 1 & 2.17 \\
\hline Astronot & Astrolog & 18 & 1 & 2.17 \\
\hline \multirow[t]{3}{*}{ Bilim insanı } & Profesör & 15 & 1 & 2.17 \\
\hline & Matematik öğretmeni & 45 & 1 & 2.17 \\
\hline & Bilgisayar mühendisi & 45 & 1 & 2.17 \\
\hline \multirow{3}{*}{$\begin{array}{l}\text { Cumhurbaşkanı } \\
\text { İş adamı }\end{array}$} & Başbakan & 19 & 1 & 2.17 \\
\hline & Cumhurbaşkanı & 43 & 1 & 2.17 \\
\hline & & 53 & $46^{*}$ & 100 \\
\hline
\end{tabular}

*Öğrencilerin ifadelerinin sıklık frekansıdır. 
Gelecekte seçmek istedikleri mesleklere ilişkin öğrenci görüşleri

Tablo 17 incelendiğinde öğrenciler \%10.87 ssklıkla öğretmenlik mesleğini doktorluk mesleğine, \%8.70 siklıkla hemşirelik mesleğini doktorluk mesleğine, \%6.52 skklikla polislik mesleğini askerlik mesleğine, $\% 4.35$ sıklıkla futbolculuk mesleğini beden eğitimi öğretmenliğine yakın gördüklerinden bahsetmişlerdir. Hemşirelik ve doktorluk mesleği sağlık alanında, futbolculuk ve beden eğitimi öğretmenliği meslekleri spor alanında, polislik ve askerlik meslekleri ise koruma ve güvenlik amaçlı meslekler arasında yer aldığı görülmektedir. Bu bulgulara göre öğrencilerin benzer dallardaki meslekleri birbirine yakın gördüğü düşünülebilir. Buna benzer olarak farklı mesleklerden yola çıkılarak bakıldığında uyumlar gözükmektedir. Bulgular incelendiğinde ressamlık moda tasarımcilı̆̆ına, moda tasarımcilığı ressamlığa, doktorluk öğretmenliğe benzetilirken öğretmenlik de doktorluğa benzetilmiştir. Bunun yanı sıra yakınlık bakımından hataların olduğu da görülmektedir. Astronot ile astrolog arasında, İngilizce öğretmeni ile arkeolog gibi meslek çalışanları arasında yanlış bağlantılar da kurulmuştur. Hemşirelik, doktorluk, öğretmenlik çok farklı meslek dallarına yakın görülürken, ressamlık, mimarlık, mühendislik, veterinerlik, polislik, askerlik gibi meslekler ise tek bir mesleğe yakın olarak görülmüştür. Gelecekte seçmek istedikleri meslek kalp cerrahı ve beyin cerrahı olan öğrenciler ise yakın gördükleri meslekleri belirtememişlerdir. Bunun nedeni olarak meslek dalındaki branşı belirttiklerinden benzetmeye gidemedikleri düşünülmektedir.

\section{TARTIŞMA, SONUÇ ve ÖNERILER}

Araştırma kapsamında ilk olarak; ögrencilerin ileride seçmek istedikleri mesleklere yönelik görüşleri incelendiğinde; öğrencilerin ağırlıklı olarak eğitim ve sağlık sektörlerindeki meslekleri tercih etmek istedikleri sonucuna ulaşılmıştır. Bu bağlamda öğrencilerin çoğunluğunun öğretmen, doktor ve hemşire olmak istemelerinin genel nedenleri; bu meslek gruplarıyla günlük hayatlarında sıklıkla karşılaşıyor olmaları ve bu mesleklerin toplumdaki tercih edilme yoğunluğundan kaynaklı olabileceği şeklinde açıklanabilir. Bandura (1986), Sosyal Bilişsel Teori üzerinden, öz-yeterlik ve öz farkındalığın önemini vurgulamıştır. Bandura tarafindan bilişötesinin ise öz-yeterlik, özfarkındalık, kaynaklık, kendini izleme, hedef belirleme, seçme, özmotivasyon ve yükleme şeklinde sekiz boyutu tanımlanmıştır (Bandura, 1986). Bireyler sahip oldukları bu boyutlarla kendi güçlü ve zayıf yönlerinin farkında olarak kendilerine uygun mesleği seçmelerinde yararı olacaktır. Ayrıca öğrenciler bu beceri ve yeterlikleri ile istedikleri bu meslek gruplarını yakından tanıma, gözlem yapabilme ve bilgi toplayabilme firsatına sahip oldukları için rol model olarak örnek almış olabilirler. Sarıkaya ve Khorshıd (2009) çalışmalarında lise döneminde öğretmenlik ve tıp gibi mesleklere yönelmeyi düşünen öğrenci sayısının fazla olmasını bu mesleklerin toplumda geniş çapta benimsenen ve kabul gören meslekler olmasına bağlı olarak açıklamışlardır. Ayrıca bu çalışma kapsamında cumhurbaşkanı ve iş adamı gibi yönetme becerisine dayalı meslekleri tercih eden öğrenci sayısının oldukça az olduğu görülmektedir. Bu durumun nedeni öğrencilerin bu meslekler hakkında yeterli bilgisinin olmaması ve bu meslek gruplarını ulaşılamaz görmeleri ile ilişkilendirilebilir. Yavuz Topaloğlu, Balçın ve Balkan Kıyıcı (2016) çalışmalarında öğrencilerin meslekler hakkında edindikleri bilgilerinin günlük hayattaki yansımalarını görmelerine imkân verilmesinin öğrencilerin mesleklere karşsı olan duyuşsal özelliklerini etkilediğini vurgulamıştır. Dolayısıyla bu yaş grubunda yer alan öğrencilerin seçmek istedikleri mesleklerin yakın çevresinde yer alan meslekler olduğu ifade edilebilir.

Öğrencilerin gelecekte seçmek istedikleri mesleklere ilişkin yaptıkları görev tanımlarına dayalı görüşleri eğitim alanındaki, güvenlik amacı güden, sağlık alanındaki, spor temelli, 
araştırma amacı güden, el becerisine ve yönetme becerisine dayalı meslek temaları altında incelenmiştir. $\mathrm{Bu}$ doğrultuda; gelecekte el becerisine dayalı meslek dallarını seçmek isteyen öğrencilerin geneli bu mesleklerde yer alan kişilerin ürün oluşturma ve bu ürünleri sunma odaklı görevlere sahip olduklarını belirtmiştir. Gelecekte eğitim alanındaki meslek dallarını seçmek isteyen öğrenciler çoğunlukla bu mesleklerde yer alan kişilerin bilgi verme görevine sahip olduklarını belirtmiştir. Gelecekte güvenlik amacı güden meslek dallarını seçmek isteyen öğrenciler bu mesleklerde yer alan kişilerin toplum içerisinde huzur bozan durumları önleme görevine sahip olduklarını belirtmiştir. Gelecekte spor temelli meslek dallarını seçmek isteyen öğrenciler bu mesleklerde yer alan kişilerin fizyolojik faaliyetlerde bulunma gibi görevlere sahip olduklarını belirtmiştir. Gelecekte sağlık alanına ait meslek dallarını seçmek isteyen öğrenciler bu mesleklerde yer alan kişilerin hastalıkları tedavi etme gibi Görevlere sahip olduklarını belirtmiştir. Gelecekte araştırma amacı güden meslek dallarını seçmek isteyen öğrenciler bu mesleklerde yer alan kişilerin bilinmeyenleri keşfetme ve bilimsel çalışmalar yürütme gibi görevlere sahip olduklarını belirtmiştir. Gelecekte yönetme becerisine sahip meslek dallarını seçmek isteyen ögrenciler bu mesleklerde yer alan kişilerin ülke içi ve dışında olumlu iletişim ve etkileşim faaliyetleri sağlama konumunda görev alma gibi görevlere sahip olduklarını belirtmiştir. Bu bulgular doğrultusunda öğrencilerin ileride seçmek istedikleri mesleklerin görev ve işlevleri hakkında tam anlamıyla eksiksiz ve detaylı açıklamalara yer vermemiş olmalarına rağmen bir takım bilgi ve farkındalıklara sahip olduğu ifade edilebilir. Bu durumun nedeni; öğretmenlerin, rehberlik servislerinin ve velilerin öğrencilere meslek gruplarının yaptıkları işler hakkında yeterli bilgilendirmede bulunmamış olmaları dolayısıyla öğrencilerin kendi gözlem ve tecrübelerinden yola çıkarak tanımlamalar yapmış olmaları olabilir. Çünkü ortaokul yılları çocuğun mesleklerin ortak ve farklı özellikleri hakkında detaylı bilgi sahibi olmaya ve mesleklerin yeni yönlerini keşfedip anlamaya başladığı yıllar olması bakımından önemlidir (Yeşilyaprak, 2008). Ayrıca Canal (2013) çalışmasında ortaokul öğrencilerinin meslek tanımları yapmalarında dizi ve film gibi televizyon programlarının, çocukların kendi gözlemleri ve ailelerinin en önemli unsurlar olduğunu vurgulamıştır.

Öğrencilerin gelecekte seçmek istedikleri meslek gruplarında çalışan bireyin kişisel özelliklerine ilişkin görüşleri eğitim alanındaki, güvenlik amacı güden, sağlık alanındaki, spor temelli, araştırma amacı güden, el becerisine ve yönetme becerisine dayalı meslek temaları altında incelenmiştir. Bu doğrultuda; öğrencilerin çoğunluğu; el becerisine sahip mesleklerde çalışan bireylerin zeki, çalışkan ve yaratıcı olma gibi bilişsel özelliklerini vurgularken; eğitim, sağlık ve güvenlik sektöründe çalışan bireylerin dürüst, güvenilir, sabırlı, adaletli, yardımsever ve meslek sevgisine sahip olma gibi bir takım duyuşsal özellikler taşıdığını belirtmiştir. Öğrencilerin bu şekilde düşünmesinin nedeni; mühendis, mimar ve moda tasarımı gibi mesleklerde çalışan bireylerin yaratıcı fikirler öne sürerek ürün oluşturmaya dayalı bilişsel faaliyetler yürütmeleri olabilir. Çünkü bu meslek grubunda yer alan bireyler üretmeye dayalı olarak insanlardan ziyade daha çok cansız varlıklar ile çalışmaktadır (Brown, 2002). Oysa öğretmenlik, doktorluk, hemşirelik, polislik ve askerlik mesleğini icra eden bireylerin görevlerinin temeli sosyal yardım odaklı olarak insanlarla olan iletişim ve etkileşime dayalıdır. Dolayısıyla öğrenciler eğitim, sağlık ve güvenlik sektöründe çalışan bireylerin duyuşsal özelliklerine ağırlıklı olarak yer vermiş olabilirler. Öğrencilerin görüşlerine benzer şekilde Stott (2007) hemşirelik mesleğinin özünün insan sevgisi ve yardımlaşmaya dayandığını vurgulamıştır. Dillon ve Maguire (2011) ise öğretmenlik mesleğinin; öğrenci odaklı olarak onların sorunlarını çözüp bilgi ve becerilerini geliştirmeye yardımcı olmayı kapsayan bir meslek 
Gelecekte seçmek istedikleri mesleklere ilişkin öğrenci görüşleri

olduğunu belirtmiştir. Buna ek olarak öğrenciler araştırma amacı güden mesleklerde çalışan bireylerin bilişsel özelliklerinden çok özgüvenli, sabırl, güvenilir ve düşünceli olma gibi duyuşsal özelliklerini vurgulamıştır. Öğrencilerin bu meslek grubunda yer alan kişilerin duyuşsal özelliklerine değinmiş olmalarının nedeni; öğrencilerin bilimsel bir araştırma yürütmenin ciddi şekilde zor ve dikkat gerektiren uzun ve meşakkatli bir süreç olduğunun farkında olmaları olabilir. Çünkü bilimsel araștırma, zor, yoğun vakit, bütçe, emek ve materyal gerektiren bir süreçtir (Usta, 2012). Bu araştırmada yer alan öğrenci görüşlerine benzer şekilde; Kara ve Akarsu (2013) çalışmalarında ortaokul öğrencilerinin, bilim insanlarının duygu ve hislerinin onların önemli özelliklerinden olduğunu düşündüklerini belirtmiștir. Bu bağlamda öğrencilerin düşünceleriyle astronot ve bilim insanlarının taşıması gereken özelliklerin örtüștüğü görülmektedir. Ayrıca öğrencilerin çoğunluğu; yönetme becerisine sahip mesleklerde çalışan bireylerin eşit oranda bilişsel ve duyuşsal bir takım özelliklerini vurgulamıștır. Bu başlık altındaki mesleklerde görev yapan kişilerin liderlik vasıflarına sahip olması beklenmektedir. Bu bağlamda bilișsel ve duyuşsal özelliklerinden birlikte bahsedilmesi beklenen bir sonuç olarak ifade edilebilir. Çünkü lider; zeki, çalışkan, sabırlı, azimli, sorumluluk sahibi, sorunlara çözüm yolu getiren, etkili konuşan ve dinleyen kişi olarak tanımlanmaktadır (Aytürk,1999). Son olarak öğrencilerin çoğunluğu; spor temelli mesleklerde çalışan bireylerin psikomotor özelliklerini vurgulamıştır. Bunun nedeni olarak öğrencilerin futbolcu ve boksör gibi meslek dallarından yola çıkarak zihinlerinde bu meslek grubunda çalsşan bireylerin sadece fiziksel özelliklerinin şekillendiği düşünülmektedir.

Öğrencilerin gelecekte seçmeyi düşündükleri mesleklerle benzerlik gösteren mesleklere ilişkin görüşleri incelendiğinde; hemşirelik ve doktorluk, futbolcu ve beden eğitimi öğretmenliği, polislik ve askerlik gibi dallardaki meslekleri birbirine yakın gördükleri sonucuna ulaşılmıştır. Bunun yanında öğrencilerin bir kısmı farklı sektörde yer alan öğretmenlik ve doktorluk mesleğini birbirine benzer gördüklerini ifade etmiștir. Bu bulguların yanında öğrencilerden çok küçük bir kısmının astronot ile astrolog, İngilizce öğretmeni ile arkeolog gibi meslek çalışanları arasında yanlış bağlantılar kurduğu göze çarpmıştır. Dolayısıyla sayıca az olmasına rağmen bazı yanılgı içeren öğrenci görüşlerinin de olduğu tespit edilmiștir. Sonuç olarak öğrencilerin genel olarak benzer meslek grupları hakkında bilgilerinin olduğu ifade edilebilir.

Ortaokul öğrencilerinin gelecekte seçmek istedikleri mesleklere ilişkin görüșlerinin belirlenmesinin amaçlandığı bu çalışma kapsamında; öğrencilerin günlük hayatta karşılaştı̆ı mesleklere daha çok yöneldiği diğer meslek grupları hakkında yeterli bilgilerinin olmadığı, benzer meslek grupları arasında bazı yanılgılara sahip oldukları, meslek gruplarında yer alan bireylerin özellikleri hakkında doğru fakat basit düzeyde bilgilerinin olduğu sonucuna ulașılmıștır. Bu kapsamda; öğrencilere farklı meslek gruplarında yer alan bireylerin katıldığı meslekler hakkında bilgilendirme amaçlı çeşitli seminerler verilebilir ya da daha ayrntılı bilgi almak için bu mesleklerde yer alan bireylerin işyerlerine ziyaretler düzenlenebilir. Meslek gelişim sürecinin ortaokul döneminde geliştiği göz önünde bulundurulduğunda bu çalışmanın literatüre katkı sağlayabileceği söylenebilir. Dolayısıyla ortaokul düzeyinde olan öğrencilerin çeşitli mesleklere ilişkin görüşlerini ve yanılgılarını belirlemeye yönelik çalışmalar yürütülebilir. 


\section{KAYNAKÇA}

Aktın, K. (2017). 6. sınıf kız çocuklarında kariyer bilinci üzerine bir araştırma. Kastamonu Ë̆itim Dergisi, 25(4), 1619-1634.

Anılan, H., Çemrek F. ve Anagün, Ş. (2008). Ortaöğretim öğrencilerinin meslek seçimi ve üniversite tercihlerine ilişkin görüşleri (Eskişehir örneği). Education Sciences, 3(2), 238-249.

Aytürk, N. (1999). Yönetim Sanatı (3. Baskı). Yargı Yayınevi: Ankara.

Bandura, A.(1986). Social foundations of though and action: A social cognitive theory. Englewood Cliffs, NJ:Prentice-Hall.

Bozgeyikli, H. (2008). Mesleki grup rehberliğinin ilköğretim 8. sınıf öğrencilerinin meslek kararı verme yetkinlik düzeylerine etkisi. Atatürk Üniversitesi Kazım Karabekir Ĕgitim Fakültesi Dergisi, 18, 36-58.

Bozgeyikli, H., Bacanlı, F. ve Doğan, H. (2009). İlköğretim sekizinci sınıf öğrencilerinin mesleki karar verme yetkinliklerinin yordayıcılarının incelenmesi. Selçuk Üniversitesi Sosyal Bilimler Enstitüsü Dergisi, 21, 125136.

Brown, D. (2002). Career choice and development. San Francisco: John Wiley \& Sons, Inc.

Can, A. ve Taylı, A. (2014). Ortaokul öğrencilerinin kariyer gelişimlerinin incelenmesi. Abant İzzet Baysal Üniversitesi Eğitim Fakültesi Dergisi, 14(2), 321-346.

Canal, M. (2013). Ortaokul sosyal bilgiler dersinde mesleklerle ilgili yaptlan etkinliklerin ögrencilerin meslek seçimine etkisinin analizi. Yayımlanmamış yüksek lisans tezi. Gazi Üniversitesi, Eğitim Bilimleri Enstitüsü, Sosyal Bilgiler Öğretmenliği Bilim Dalı, Ankara.

Çoban, A. E. (2005). Lise son sınıf öğrencilerinin mesleki olgunluk düzeylerinin yordayıcı bazı değişkenlere göre incelenmesi. Inönü Üniversitesi Ĕgitim Fakültesi Dergisi, 6(10), 39-54.

Deniz, S. (2001). Bireyin meslek seçimini etkileyen kaynaklar: Yeni teknolojilerden internet. Muğla Üniversitesi SBE Dergisi, 6, 36-44.

Dillon, J., \& Mague, M. (2011). Developing as a student teacher. J. Dillon \& M. Mague (Eds.). In Becaoming a teacher içinde (pp.3-12). Berkshire: McGraw-Hill Educations.

Dornyei, Z. (2007). Research methods in applied linguistics. New York: Oxford University Press.

Gottfredson, L. S. (2002). Gottfredson's theory of circumscription, compromise and selfcreation. D. Brown \& Associates (Eds.). In Career choice and development (pp.101-106). Bensenville: Scholastic Testing Service.

Herr, E. L., Cramer, S. H., \& Niles, S. G. (2004). Career guidance and counseling: Through the lifespan (6th ed.). Boston: Pearson Education Inc. 
Gelecekte seçmek istedikleri mesleklere ilişkin öğrenci görüşleri

Işıklar, A, ve Bozgeyikli, H. (2010). İlköğretim öğrencilerinin kariyer gelişimlerinin demografik faktörler açısından incelenmesi. Sakarya Üniversitesi Eğitim Fakültesi Dergisi, 19, 10-29.

Kara, B. ve Akarsu, B. (2013). Ortaokul öğrencilerinin bilim insanına yönelik tutum ve imajının belirlenmesi. Journal of European Education, 3(1), 8-15.

Kuzgun, Y. (1986). Meslek seçiminde kararsızlı. Ankara Üniversitesi Eğitim Fakültesi Dergisi, 19(1),217-223.

Mcintosh, P. I. (2000). Life career development: Implications for school counselor. Career Education, 120, 621-626.

MEB (2013). Talim ve Terbiye Kurulu Başkanlı̆̆g, İlköğretim Kurumları Fen Bilimleri Dersi (3,4,5, 6, 7 ve 8. Sinıflar) Öğretim Programı. Ankara: MEB Yayınları.

Özen, Y.(2010). Televizyonun ilköğretim 7. sınıf öğrencilerinin meslek seçimiyle ilgili algılarına etkisi. Ë̆itim ve İnsan Bilimleri Dergisi. 1(2), 61-80.

Patton, M. Q. (2001). Qualitative research and evaluation methods (2nd Edition). Thousand oaks, CA: Sage Publications.

Sarıkaya, T., \& Khorshid, L. (2009). Üniversite öğrencilerinin meslek seçimini etkileyen etmenlerin incelenmesi: Üniversite öğrencilerinin meslek seçimi. Türk Eğitim Bilimleri Dergisi, 7(2), 393-423.

Stott A. (2007). Exploring factors affecting attrition of male students from an under graduate nursing course: A qualitative study. Nurse Education Today, 27(4),325-332.

Sukiennik, D., Bendat, W., \& Raufman, L. (2004). The career fitness program: Exercising your options. New Jersey: Pearson Prentice Hall.

Super, D. E. (1963). Self-concepts in vocational development. Career development: Self-concept theory, 1-16.

Super D. E. (1990). A Life-Span, Life-Space Approach to Career Development. In D.Brown \& L. Brooks (Edit.) Career Choice and Development: Applying Contemporary Theory to Practice (pp.197-261). San Francisco: Jossey-Bass.

The Organisation for Economic Co-operation and Development [OECD]. (2014). Youth Unemployment Rate. Date of access: 18.08.2017, URL: https://data.oecd.org/unemp/youth-unemployment-rate.htm.

Turner, S., L., \& Lapan, R., T., (2005). Evaluation of an intervention to inerease nontraditional career interests and career-related self-efficacy among middleschool adolescents. Journal of Vocational Behavior, 66(3), 516-531.

Türkiye İstatistik Kurumu [TÜIK], (2017). İşgücü istatistikleri, Mayls 2017. Erişim tarihi: 18.08.2017

URL: http://www.tuik.gov.tr/HbGetirHTML.do?id=24630

Usta, A. (2012). Bilimsel araştırmalarda yapısal etmenler ve evreler. İnönü Üniversitesi Uluslararast Sosyal Bilimler Dergisi, 1(1) 97-112. 
Ünlü, İ. (2010). Televizyonun ilköğretim 7. sınıf öğrencilerinin meslek seçimiyle ilgili algılarına etkisi. Erzincan Ë̆itim Fakültesi Dergisi, 12(2), 55-73.

Yanıkkerem, E., Altınparmak, S. ve Karadeniz, G. (2004). Gençlerin meslek seçimini etkileyen faktörler ve benlik saygıları. Nursing Forum Dergisi, 7(2), 61- 62.

Yavuz Topaloğlu, M., Balçın, M. D. ve Balkan Kıyıcı, F. (2016, Mayıs). Fen bilimleri ögretim programında yer alan fen ve kariyer bilinci konusuna yönelik ögretmen düşünceleri. VII. Uluslararası Eğitim Araştırmaları Kongresi, 18 Mart Üniversitesi, Çanakkale. Türkiye.

Yeşilyaprak, B. (2008). Eğitimde rehberlik hizmetleri. Ankara: Nobel Yayıncılık.

Yeşilyaprak, B. (2011). Mesleki rehberlik ve kariyer danışmanlığında paradigma değişimi ve Türkiye açısından sonuçlar: Geçmişten geleceğe yönelik bir değerlendirme. Kuram ve Uygulamada Ĕ̆itim Bilimleri, 11(4), 5-26.

Yıldırım, A., \& Şimşek, H. (2013). Sosyal bilimlerde nitel araştırma yöntemleri. Ankara: Seçkin Yayıncılık. 


\section{EXTENDED ABSTRACT}

\section{Introduction}

Vocational development is a process which has its origins in primary and secondary school periods and proceeds to develop throughout the life. In primary and secondary school periods, individuals acquire knowledge, attitudes and behaviors to get qualified for choosing between a wide variety of professions (Gottfredson, 2002). Students can be provided with the opportunity to have a healthier educational future and choose the best profession among several alternatives through the works towards determining their fields of interest, anxieties and uncertainties they undergo regarding professions and their knowledge and skill levels. In this context, this study was performed with a view to contribute to the related field. Moreover, wrong choices of profession in our country related to provision of inadequate educational level leads to higher numbers of unhappy and unsuccessful individuals in the society who have difficulties in finding a job; and in this context, this study holds importance in terms of determination of the current knowledge, expectations and perceptions of secondary school students regarding professions. Additionally, considering that the decisions taken and information acquired in primary and secondary school ages have a fundamental role in choice of profession; this study is also important as it aims to determine the opinions of 6th grade secondary school students on the professions they tend to choose.

\section{Method}

The study was carried out using phenomenological research design among qualitative research methods. The study group of the research consists of 53 students receiving education in the sixth grade of a secondary school in Bitlis province Adilcevaz district as of 2016-2017 educational period. Convenience sampling method was used in determination of the study group.

A form including four open-ended questions was used as data collection tool. Within the scope of the research, initially, a draft questionnaire form was prepared as a new data collection tool. Afterwards, this draft form was subjected to peer and expert review by to science instructors, and implemented on students at the same age. The data collection tool was accordingly finalized using the feedbacks received from these applications.

The questions in the final version of the form are as follows:

- What is the profession that you want to choose in the future?

- Define the profession that you want to choose in the future. What kind of works does a person in this profession do?

- Write down the personal characteristics of a person working in this profession.

- Which professions show similarities with this one?

Content analysis was used for evaluation of the data obtained in this research. The data obtained from the content analysis are presented in the tables in which codes, theme titles and percentages are given. Various validity and reliability studies such as expert 
review, diversification of researchers in data analysis, and inclusion of the participant responses to open-ended questions were performed within the scope of the research.

\section{Findings, Discussion and Results}

Student opinions towards the professions they want to choose in the future indicate that, the majority of participants prefer the professions in the fields of education and health. Also, few students stated to prefer professions based on administrative skills such as president of the republic or businessman.

Student opinions based on the job descriptions as to the professions they want to choose in the future were investigated under the following themes: professions in the fields of education, security, health, sports, research, based on hand skills and management. In this regard, majority of the students that tend to choose hand-skill-based professions stated that individuals engaged in such type of jobs undertake product-manufacturing and presentation related tasks. Students that want to choose professions in the field of education stated that, individuals in this field undertake the task of instructing and informing. Those that want to get engaged with professions in the field of security stated that, individuals in such professions are involved in prevention of situations that provoke disturbance. Students that want to choose professions in the field of sports stated that, individuals in this field take on tasks such as performing physiological activities. Students that want to choose the professions in the field of health stated that, such individuals take on responsibilities such as treating diseases. Students that preferred to choose the field of research stated that individuals working in this field have tasks such as discovering and performing scientific research. Students that stated to be tended towards professions with administrative-management skills stated that, individuals who are involved in such professions undertake tasks such as providing positive inland and abroad communication and interaction activities.

Students' opinions on the personal characteristics of individuals involved in professions in which they want to choose in the future were investigated under the themes of educational, security-related, health-related, sports-based, research-driven, hand and management skills-based professions. In this respect, majority of the participants emphasized the cognitive features of individuals working in hand-skills-based professions such as being smart, hardworking and creative; and stated that those working in education, health and security related professions are generally characterized with affective features such as being fair, reliable, just, charitable and having professional ethics. In addition, majority of the participants mentioned the affective attributes of individuals engaged in research fields such as being highly selfconfident, patient and thoughtful. They also emphasized some of the cognitive and affective characteristics of individuals with high management skills at an equal rate.

The students' opinions on the professions which show similarities with those they tend to choose in the future indicate that, they regard professions such as nursery, surgery, football player, and physical teaching as similar professions. Additionally, some of the students stated that they regarded teaching and medicine-related jobs as similar professions. It was also detected in addition to these findings that, some of the students established false connections between professions such as astronauts and astrologists, English teachers and archaeologists. 
Within the context of this work which aims to determine the opinions of secondary school students on the professions they want to choose in the future, it was concluded that, students are mostly apt to choose among the professions that they encounter in their daily lives and not well-informed about other professions, they are misinformed about similar groups of profession, and they have correct information about the individuals in mentioned professions but this knowledge remains at elementary level. In this respect, students can be provided with seminars for information purposes with participation of individuals from different groups of profession, or visits can be organized to the workplaces of these individuals for getting more detailed information. Additionally, studies can be conducted to determine the opinions and misconceptions of secondary school students regarding different professions. 